Portland State University

PDXScholar

$11-1-1994$

\title{
Comparison of Training Methods in a Branch Environment
}

Lisa Peterson Davidson

Portland State University

Follow this and additional works at: https://pdxscholar.library.pdx.edu/open_access_etds

Part of the Speech and Rhetorical Studies Commons

Let us know how access to this document benefits you.

\section{Recommended Citation}

Davidson, Lisa Peterson, "Comparison of Training Methods in a Branch Environment" (1994).

Dissertations and Theses. Paper 4725.

https://doi.org/10.15760/etd.6609

This Thesis is brought to you for free and open access. It has been accepted for inclusion in Dissertations and Theses by an authorized administrator of PDXScholar. Please contact us if we can make this document more accessible: pdxscholar@pdx.edu. 


\section{THESIS APPROVAL}

The abstract and thesis of Lisa Peterson Davidson for the Master of Science in Speech Communication were presented November 1, 1994, and accepted by the thesis committee and the department.

COMMITTEE APPROVALS:

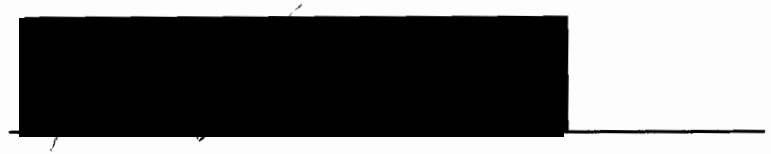

Larry steward, Chair

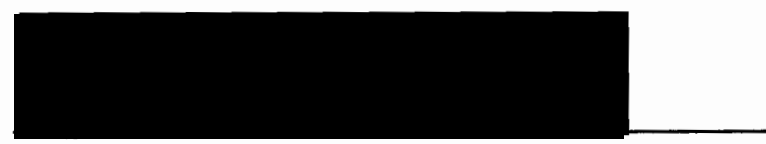

Leslie Good

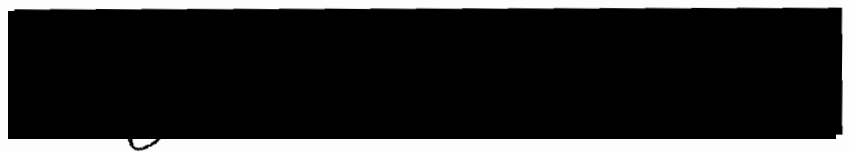

Doug Robertson

DEPARTMENT APPROVAL:

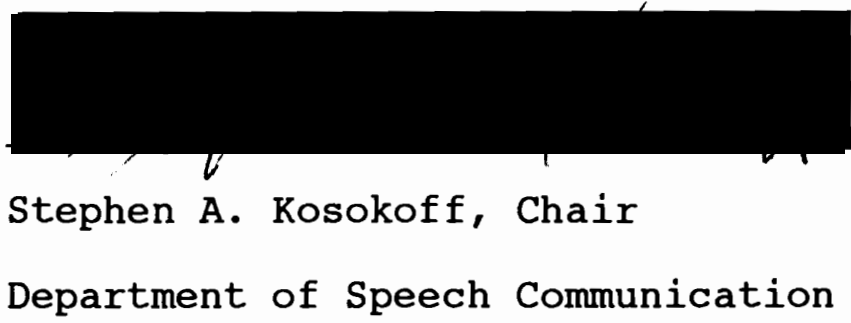

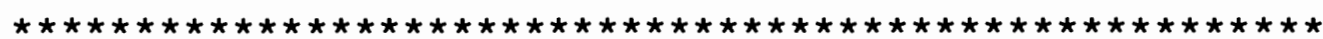

ACCEPTED FOR PORTLAND STATE UNIVERSITY BY THE LIBRARY

by

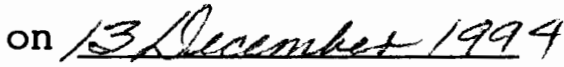




\section{ABSTRACT}

An abstract of the thesis of Lisa Peterson Davidson for the Master of Science in Speech Communication presented November 1,1994

Title: Comparison of Training Methods in a Branch Environment.

This study addressed a need to identify the effectiveness of in-branch, employee administered training programs. A comparison of various training methods and a ranking of the effectiveness of those methodologies would enable managers to make informed training design and purchase decisions.

The purpose of this study was to determine the differences between four training methods as evaluated by post-training assessment scores. This study also sought to determine the following: 1) did all four methods significantly impact short term material recall?, and 2) did gender impact training effectiveness? The training methods studied were: video; study guide; video plus study guide; video and study guide plus reinforcement meeting. A control group was used to obtain a pre-training baseline.

One hundred eighty two employees who worked at one of twenty randomly selected Portland, Oregon branches of a large, 
regional bank participated in the study. Each branch utilized one of the five randomly assigned methods in a scheduled staff meeting. After completing the training, each participant completed a post training assessment testing material recall. The control group completed the assessment without participating in training.

Analysis of Variance tests were used to determine if significant differences existed between: 1) the mean scores of the control group and the training methods, 2) the mean scores of the training methods themselves, and 3) the mean scores of males and females. A significant difference was found at the .05 level between the mean scores of the control group and every training method except video. There were no significant differences between the mean scores of the four training methods. There was not a significant difference between the mean scores of males and females. There was also no significant difference in method effectiveness based on gender. 
COMPARISON OF TRAINING METHODS IN A BRANCH ENVIRONMENT

\author{
by \\ Lisa Peterson Davidson
}

A Thesis Submitted in Partial Fulfillment of the Requirements for the degree of Master of Science in Speech Communication

\author{
Portland State University \\ 1994.
}




\section{CHAPTER I: TUE PROBLE财}

\section{INTRODUCTION}

Employee training is costing organizations billions of dollars annually. Organizations with over 100 employees spend more than $\$ 45$ billion annually on formal training (Gordon, 1990). Kelly (1982) found that corporate training and development expenditures top $\$ 100$ billion annually. These large budget allocations indicate that corporate managers acknowledge that training is beneficial to the corporations.

While working as a training manager for a large regional financial institution, I discovered that although the corporation recognized that in-service training can positively impact profits and employee morale, the travel costs, salary dollars, training material costs, and streamlined staffing levels make it very difficult to pull people out of their work environments for training. Even though training is deemed worthwhile, the costs may be thought to outweigh the benefits. The training managers I worked with inside and outside the organization are looking for the quickest, least expensive, least disruptive yet effective training methods available. 
Representatives from BankTraining and Bankers Training and Consulting (vendors of video-based training) stated in telephone interviews I conducted that video and computerbased training program sales are increasing. Training Magazine stated that 88.78 of the organizations they surveyed use video based training; the highest percentage of any training method (Gordon, 1990). Approximately fifty percent of the training requests I received as training manager were for video, self-study (written, video or computer based training which can be completed by each employee independently on his/her work site) and on-site staff meeting training formats due to limited budgets and staffing levels.

The challenge to individuals developing training programs is to choose the most appropriate training method for the training environment, keep within cost and staffing constraints, and ensure that employees will learn the material and transfer the learning to their work environments. Very little empirical research has been done in the area of training methodology making it difficult to confidently select the most appropriate training method and defend the selection if questioned. Empirical research is necessary to outline the pros and cons, and expected results of utilizing a particular training methodology to address a training need. This information will enable corporate managers to make informed decisions. 


\section{PURPOSES AND OBJECTIVES}

The objective of this study is to test whether there is a difference in training effectiveness of A) video alone, B) self-study alone, C) video plus self-study, and D) video, self-study and brief reinforcement meeting. These four methods were selected, because a large, multi-state bank has chosen to provide product training to be delivered throughout their branch network and has utilized this design. Training managers wanted to determine if there is a significant difference in the effectiveness of the training if the video, study guide and reinforcement meetings are combined. The training managers also wanted to determine if there is a difference in the effectiveness of the four methods based on gender. The managers felt that if significant gender differences were discovered, training design might be impacted in the future. Due to the importance placed on possible gender differences by the managers, the independent variable, gender, was included in the main study.

Other questions which were peripheral to the main study having to do with race/national origin and age were asked at the request of the bank managers. While not a part of the main study, these findings will be examined following the main analysis to discover any additional insights which would help in the interpretation of the study or provide a basis for additional study. These exploratory findings 
will be addressed in the section entitled "Observations After the Main Study".

The variables in this study are:

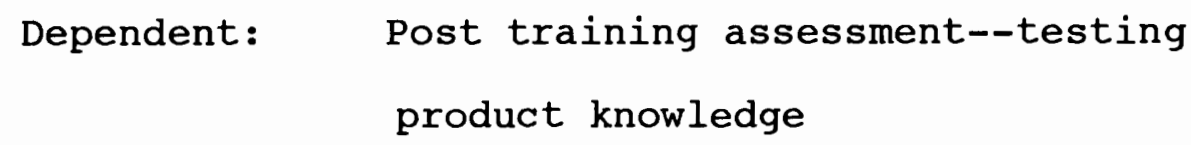

$\operatorname{Sex}$

Male

Female

\section{RESEARCH DESIGN}

1. The participants were employees who work in the branch network of a large, multi-state bank. They hold 
a variety of jobs from customer service representative to branch manager.

2. The post training assessment was called "Product Knowledge Training Survey". It included 14 questions (22 scorable items) which were answered in the product training. The participants did not know which questions would be asked prior to the training. The post training assessment was completed by each participant immediately after the training.

3. The scores of the control group assessment and the four training method assessments were compared to evaluate training effectiveness overall, and to discover any differences in effectiveness due to gender. The method(s) yielding the highest significant percentage gain(s) in post training assessment scores over the control group assessment scores were classified most effective. The other methods were ranked according to their significant percentage gain over control group scores.

4. The post training assessment measured learning in terms of short term material recall. 
5. The video, self-study materials, and reinforcement meeting guide were developed by the bank training department.

6. The video is a 5 minute professionally produced training piece which includes product details and a role play.

7. The self-study is a workbook which contains product information, and questions reinforcing written and video material. Each student completed the workbook prior to the video presentation. The self-study condition utilizes a workbook which is a stand alone training tool and can be used without utilizing the video.

8. The 15-30 minute reinforcement meeting was led by a branch representative. It was designed to review the important product details presented in the video and self-study.

I conducted a field experiment using a Post training assessment-only Control Group design. The sample was all branch employees working in randomly selected branches in the greater Portland, Oregon area. The training method for each branch was randomly determined. I worked with independent variables in all groups. A control group completed 6 
the post training assessment without completing the training. The control group scores were used as the pre-training skill baseline. This study investigated the relationship between variables.

\section{RESEARCH QUESTION}

The following research question was addressed:

1) Will a significant difference in the test scores measuring material recall exist between those who participate in video training, self-study training, video plus self-study training, video plus self-study with reinforcement meeting training, and those who do not participate in training, based on gender?

\section{SUMMARY}

Corporations recognize the importance of in-service training. However, training directors are charged with developing the most effective, least costly, least disruptive training possible. The various training methods need further research. 
This study compared the effectiveness of stand alone video, self-study training, video plus self-study, and video plus self-study with reinforcement meetings. It researched whether there was a significant difference in the training methods as measured by material recall. 


\section{CHAPTER U: REVIEW OF LUTERATURE}

A number of studies have been conducted to identify the most effective training methods. Berliner and Rosenshine (1975), and McKeachie (1971) found that people learn differently; so each training method may influence learning in some people and not be the best method for others. Womak (1989) suggests that certain assumptions about learners are inherent in each method, and those assumptions must be true for the learning experience to be satisfactory for the student. Tough (1971) found that people use a variety of methods to learn. Gist, Bavetta and Stevens (1990) state that the presentation of the initial training content significantly influences transfer of learning.

\section{TRAINING METHODS}

Researchers have studied particular training methods and have concluded that certain methods are superior to others. However, they did not arrive at the same conclusions. For example, consider the lecture method. Kreitlow (1976) states that lecture gives the most consistent results in learner outcomes, and a live researcher enhances the effectiveness of the lecture. Kreitlow also asserts that using film yields results similar to live lecture. Andrews (1981) states that lecture is effective, but its success may vary with content, objectives and complexity of material. 
Interactive video and self-paced learning are other methods worth reviewing. O'Sullivan, Stroot, Tannehill and Chou (1989) assert that interactive video is superior to other instructional technology, because it combines computer with video. It allows students to get immediate feedback on correct or incorrect answers, reinforcing accurate responses. Gist, Schwoerer and Rosen (1988) suggest that using video to show modeled behavior enhances learning more effectively than straight tutorial without visual behavior modeling. Belbin (1970) found that experiential and self-paced learning are effective for older adults ( 40 and older).

Some researchers say that the various methods show little differences in effectiveness. Murphy (1977) states that few, if any, differences exist between the effectiveness of different instructional methods. Gall and Gall (1976) recommend that researchers not spend additional time researching whether real differences exist between the effectiveness of lecture vs. discussion as researchers will not find conclusive evidence showing a difference in effectiveness.

\section{TEACHING STYLE}

The teacher's style can influence learning. Potter and Emanuel (1990) studied teaching style and its impact on learning. They suggest that a student's liking of 
lecture is linked to the teacher's style, expressiveness, and substance. However, McDiarmid (1990) found that some teachers have assumptions about learning such as if you tell the class something, you have taught the class. McDiarmid states that those teachers feel their role is to tell, show or explain procedure, propositions, facts and ideas.

Pat Guild asserts that if you use a variety of training methodologies addressing various learning styles, it will promote achievement, self-confidence, and remove learning barriers (Brandt, 1990).

\section{LEARNING STYLES}

Research has been conducted to determine if learning style effects the transfer of learning. Andrews (1981) asserts that experiential learning activities are a more effective method for adults to achieve cognitive gains. Andrews quotes the results of a Corpsmember Training Institute study which found "when adults are more personally and actively involved in the learning situation, they learn more cognitive material" (Andrews, 1981, p. 16). He goes on to state that instruction should be personalized, and that activities which involve active rather than passive listening improve alertness which translates into improved learning in most groups . 
Knowles (1973) says that the learning styles of adults are different than those of children, because adults need to be involved in their own learning. Adults want immediate application of learning. They want relevant, job-related, educational experiences. Newstrom (1991, p.46) says "It is necessary to adapt training programs to the different needs among adults". Elliot (1975) and Warnat (1979) agree that adults have different learning styles. Warnat (1979)

believes that adults have peaks in creativity, and a physical and professional sense of self. He states that adults have more experiences and they realize that talent and determination do not guarantee success.

Houle (1961) believes that adults take courses, because they believe they will benefit from the activity. He also states that adults choose to pursue education for three reasons: activity (relief from boredom or to meet people), goals (belief that education will contribute to the achievement of a goal), and learning (learning itself). Knowles (1970) also states that adult learners are self-directed, meaning they choose what and how to learn. Andrews reinforces that point. "If an adult does not want to learn, the adult will not learn... Adults seldom learn, remember and use answers for which they do not already have the question" (Andrews, 1981, p. 22 ). 
Studies on classroom instruction should also be considered as corporate training often takes place in a similar setting. Potter and Emanuel (1990) emphasize that training should recognize that learning styles are important to the success of learning. Beacham (1991) suggests that in order to get the participation of every student, the instructor needs to create an environment where every trainee feels confident participating. Also the instructor needs to design activities which emphasize different learning styles. Dunn (1990) says that studies repeatedly have shown that students taught with methods coinciding with their learning preferences (as identified by Dunn's "Learning Style Inventory") have achieved higher achievement and aptitude test scores than those who are not taught in their learning style preference. Dunn, Beaudry and Klavas (1989) state that students learn easily and have better retention when taught through their learning preference and in their learning environment preference. Shands and Brunner (1989) studied using learning styles with special education students. Before the learning style methodology was put in place, $25 \%$ of the students passed their exams. The first year the new methodology was used, 918 passed.

There are many different learning style theories being researched. Grasha-Riechmann (1983) suggest that there are six learning styles which should be considered in order to effectively train others. They are: dependent, 
independent, competitive, collaborative, participative and avoidant. McCarthy (1990) suggests that there are four major learning styles; imaginative learners, analytic learners, common sense learners, and dynamic learners. She asserts that training needs to address those styles as well as the left side/right side of the brain learning differences in order to train others to optimal effectiveness.

Snow and Lohman (1984) recommend that a student's learning style should be matched with instructional methodology at first, but then systematically mismatched as the student becomes confident with the material. They feel this will help students learn to develop a variety of strategies to handle the diverse situations they will have to experience in their lives.

Curry (1990) questions learning style research. She states that learning style theory has confusing definitions, e.g.. all theories predict different behaviors relating to the various learning styles. She also calls the reliability and validity of the measurements into question. And finally, Curry asserts that there is no consistency in the identification of relevant characteristics in learners and training settings across theories. She states that some studies support learning style theories; other studies show that there is no effect attributable to learning style variation. 


\section{IMPROVING TRAINING EFFECTIVENESS}

Researchers recommend a variety of ways to improve the effectiveness of training efforts. Georgenson (1982) estimates that only 108 of companies' training investment results in behavior change. Gist, et al. (1990) asserts that if trainees augment basic instructional content with goal setting activities related to transfer of learning and/or self-management of learning and application of learning, it will improve the return on training investment. Ganster, Williams and Poppler (1991) suggest that organizations may get $a$ better return on investment if they concentrate on improving the technical knowledge of employees (i.e.. increasing the knowledge of the company's products, and skills needed to perform the job) rather than spending effort on improving the ways in which they use existing knowledge (i.e. how to identify needs of customers and recommend benefits of appropriate products).

\section{VIDEO, COMPUTER BASED TRAINING AND INTERACTIVE VIDEODISC}

Corporations are increasingly looking for less expensive yet effective alternatives to classroom training, and many are turning to video and computers for solutions. Ross (1988, p.23) shows a chart from Lakewood Research which outlines the training technologies in use in 1987 at US companies with 50 or more employees. Here are the results: $35 \%$ use 15 
computer-based training; 3.98 use interactive videodisc; 20.38 use teleconferencing; and 83.2 use videotape. Because these technologies are so widely used, a review of literature in the area of audio visual training alternatives is in order. I concentrated on video, computer-based training ( video disc combined--training regulated by learner response).

Bertrand (1990, p.18) quotes a representative from Bell South who says they've experienced a " $40 z$ higher retention rate" with interactive video (IV) as compared with classroom training, and the training takes one fifth the time. Ross (1988, p.20) quotes a Xerox claim which says IV "reduces training time by $30 \%$ and increases the learning rate by $40 \%$."

Cockayne (1991) looked at the effectiveness of Interactive Videodisc (IV) in a small group (up to 5 people) versus individual instruction. According to Cockayne, IV is generally thought to be an individualized training medium. She found that the post test scores showed no significant difference between group and individualized training.

Burwell (1991) studied the interaction of learning styles on the effectiveness of IV. He found that there was no significant difference in the test scores of the students with different learning styles. Burwell also found that more $\begin{array}{ll}\text { learning occurred using IV than a study guide only. } & 16\end{array}$ 
Phillips, et al. (1988) found that students who used IV which included embedded fact based questions throughout the session achieved higher post test scores than those who used IV with no questions.

Bosco and Wagner (1988) compared Interactive Laser Disk (ILD) and video tape for safety instruction. They found that there was a higher achievement from ILD. There were more low test scores from video tape students and more high scores for ILD users. Eighty percent of the students preferred ILD.

Spitzer, et al. (1989) compared videotape and lecture formats. There were 3 groups: 1) lecture, 2) videotape, 3) students who were the audience during the taping of the video. They found that the grades were higher for students in the video tape group. The drop out rate was higher for lecture than video, however, video and taping students were significantly less satisfied than lecture students.

Gagliano (1988) conducted a review of 25 studies in the medical field which used film or videotape for patient education to assess the efficacy of using video for this population. She found that in all the studies short term knowledge increased as a result of the video training. Gagliano also found that video plus lecture or counseling produced higher test scores than lecture or counseling alone. Fox (1988) reviewed 58 skill training studies 
including CBT, sensitivity training and behavior modeling using videotape. He found behavior modeling to be significantly more effective at creating behavior change than the other methods.

Osguthorpe, et al. (1983) compared video, video plus written material, written material and regular inpatient instruction. They found no significant difference in the test scores of the four groups. Stalonas, et al. (1979) compared video, live lecture and written material. They found that videotape students scored higher than the other methods.

Even though Interactive Videodisc has shown to be more effective than videotape in short term recall measures, the cost is a deterrent to using the system exclusively and/or immediately in all corporations. Video training, on the other hand, is widely used and the research supports its effectiveness. Additional research is needed to determine if the effectiveness of video in a corporate non-classroom training environment can be improved by combining it with other mediums. 
CHAPVER TOH: RESEARGM METMODOLOGY

\section{INTRODUCTION}

Studying effective, conservatively priced training methods is of paramount importance to training directors. This research examines the effectiveness of video training vs. self-study training vs. video plus self-study training vs. video plus self-study with reinforcement meeting training. This chapter will address the methods used in this study to determine training effectiveness.

\section{DESCRIPTION OF METHODOLOGY}

This study was a Post training assessment-only with Control Group experimental field research project using a group sample of 182 bank employees in Oregon. The study included a 14 question post training assessment $(22$ scorable items testing material recall), video, self-study materials, and reinforcement meeting materials. The relationship between the variables was correlational.

Participating branches were randomly selected from the

Portland area branch network of a bank. Each 
branch was randomly assigned one of 5 training methods to use during a branch training meeting (video only, self-study only, video plus self-study, video plus self-study with reinforcement meeting, or control group--no training.)

In the training branches, the post training assessment was administered at the conclusion of the appropriate training session. The control group branches attended a staff meeting and completed a post training assessment. No training was given. The post training assessments were collected by a branch assistant when completed.

\section{RESEARCH DESIGN}

\section{Dependent variable}

a) Post training assessment. The post training assessment was an assessment of knowledge of a credit product. In all cases, except in the control group branches, the post training assessment was completed after receiving line-of-credit product training. 


\section{Independent variables}

a) Video. The video includes product information, selling tips and a role play to model how to offer the product to a customer.

b) Self-study materials. The self-study materials include written training materials covering product information and written exercises to apply information.

b) Reinforcement Meeting Guide. The meeting guide includes written training tips, key product knowledge facts to review, and optional group activities to reinforce video and meeting information.

\section{RESEARCH QUESTION}

1) Will a significant difference in the test scores measuring material recall exist between those who participate in video only, self-study only, video plus self-study, video plus self-study with reinforcement meeting, and those who do not participate in training, based on gender? 
To answer this question I compared the post training assessment scores which measured the participant's product knowledge before (control group) and after training. I also looked at the additional demographic identifier, gender, which was requested in part I of the post training assessment (see appendix 1).

\section{INSTRUMENTATION}

To collect data, I used a 14 question post training assessment. To evaluate the effectiveness of the four training methods, I utilized an Analysis of Variance. An Analysis of Variance (ANOVA) analyzes the independent variables in a study and defines how they interact with each other and how each independent variable affects the participant's response. A factorial ANOVA was the appropriate statistical procedure for this study as it is used to determine the differences between two or more groups which are created from two or more independent variables (training methods) impacting one dependent variable (posttraining assessment). 


\section{PROCEDURES}

1) Twenty branches were randomly selected from one financial institution's Portland, Oregon 170 branch network. The sample consisted of all employees in the branch who attended the scheduled product staff meeting. The employees held one or more of the following positions: Teller, New Accounts, Operations, or Lending officer. All employees were strongly urged to participate, however, participation was not mandatory. Some self-selection may have occurred. The sample size was 182 people.

2) The type of training each branch received was randomly determined.

3) The branch manager conducted the training and administered the post training assessment. Two to four weeks prior to conducting the research, the manager received a confidential package containing a cover memo, instruction sheet on how to conduct the research and all necessary materials. Two weeks prior to the research, the managers participated in a tele-conference or one-on-one conversation with researcher to carefully review the procedures (see appendix 2, 3 and 4 for copies of cover memos, instruction sheets and tele-conference notes). 
3) All participants at a selected branch completed the same type of training as a group, i.e. video only, self-study only, video plus self-study, video plus self-study with reinforcement meeting, or no training (control group.)

4) The participants completed the post training assessment immediately upon completion of the training program. The control group participants completed the assessment at the start of a scheduled staff meeting. Post training assessments were collected at the meeting, and delivered to the researcher.

5) The post training assessment scores entered on a data base to compare at the completion of the study.

\section{PLANNED STATISTICAL ANALYSIS}

I chose to use the difference analysis called Analysis of Variance. The results will be graphed as follows:

\begin{tabular}{|l|l|l|l|l|l|}
\hline & $\begin{array}{l}\text { Control } \\
\text { Group }\end{array}$ & Video & $\begin{array}{l}\text { Study } \\
\text { Guide }\end{array}$ & $\begin{array}{l}\text { Video \& } \\
\text { Study } \\
\text { Guide }\end{array}$ & $\begin{array}{l}\text { Video } \\
\text { Study } \\
\text { Guide \& } \\
\text { Meeting }\end{array}$ \\
\hline $\begin{array}{l}\text { Male } \\
\text { Scores }\end{array}$ & & & & & \\
\hline $\begin{array}{l}\text { Female } \\
\text { Scores }\end{array}$ & & & & & \\
\hline
\end{tabular}




\section{SUMMARY}

This study used a sample of 182 employees who were tested on product knowledge after receiving training by means of a video, self-study, video plus self-study, or video plus selfstudy with reinforcement meeting. A control group which received no training was utilized to determine pre-training product knowledge. I utilized an Analysis of Variance to rank the effectiveness of the selected training methods. 
This study sought to determine the differences between 5 training methods as evaluated by post-training assessment scores. The post-training assessments tested immediate material recall of information covered in the training and were administered immediately upon completion of the training.

\section{Sample}

One hundred eighty two people participated in this study. The participants worked in randomly selected branches of a large, West Coast bank. All employees in the selected branches were asked to participate. Age, sex, race, time in banking/job, previous credit training, and job assignment information was requested to clearly describe the sample. Here is the sample breakdown:

Total sample: 182 people 
Sex

\begin{tabular}{|l|l|l|}
\hline & Male & Female \\
\hline$\#$ & 21 & 161 \\
\hline 8 & 11.54 & 88.46 \\
\hline
\end{tabular}

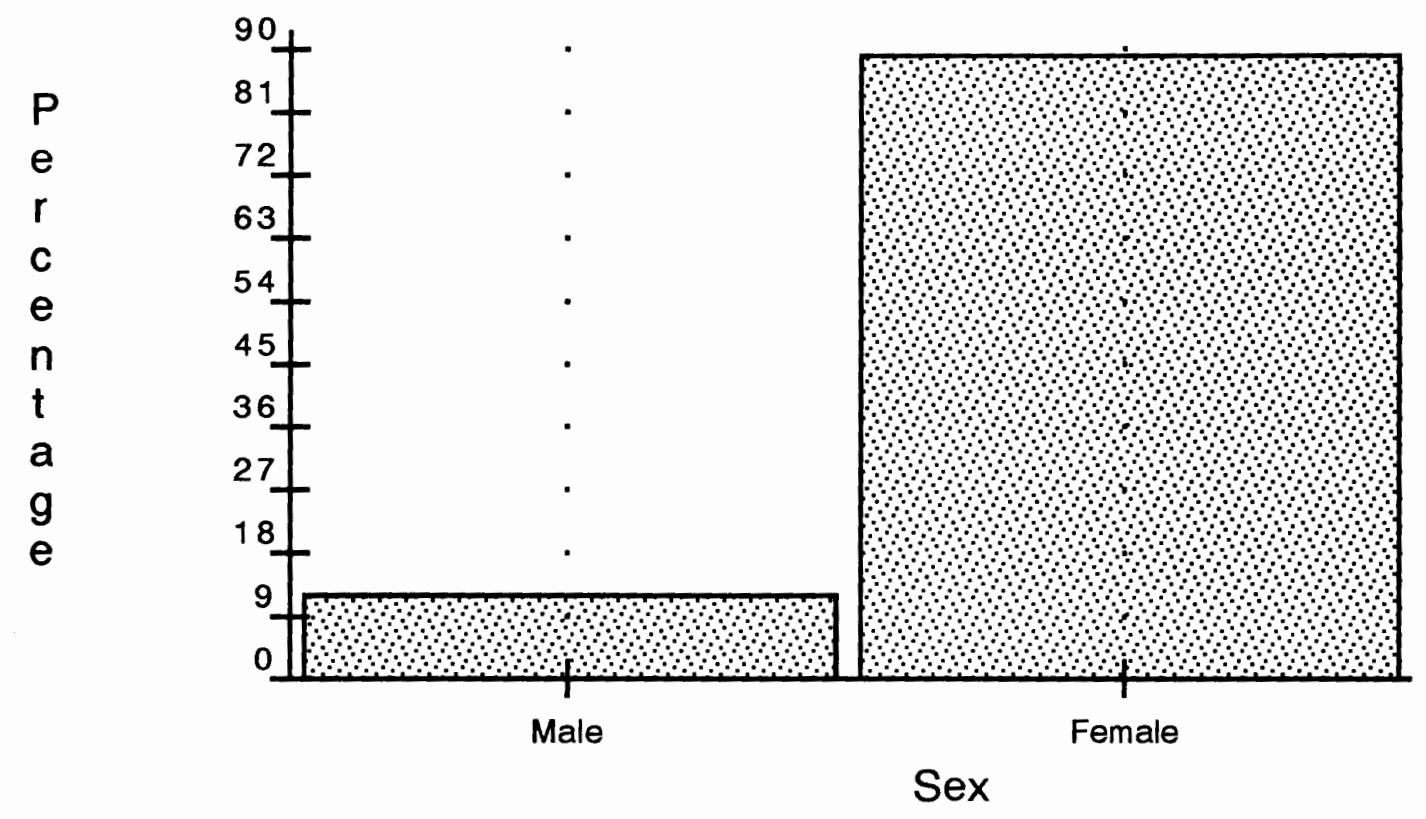

011.54 
Age

\begin{tabular}{|l|l|l|l|l|l|}
\hline & $0-20$ & $21-35$ & $36-50$ & $51+$ & N/A \\
\hline$\#$ & 9 & 78 & 76 & 17 & 2 \\
\hline 8 & 4.95 & 42.86 & 41.76 & 9.36 & 1.10 \\
\hline
\end{tabular}

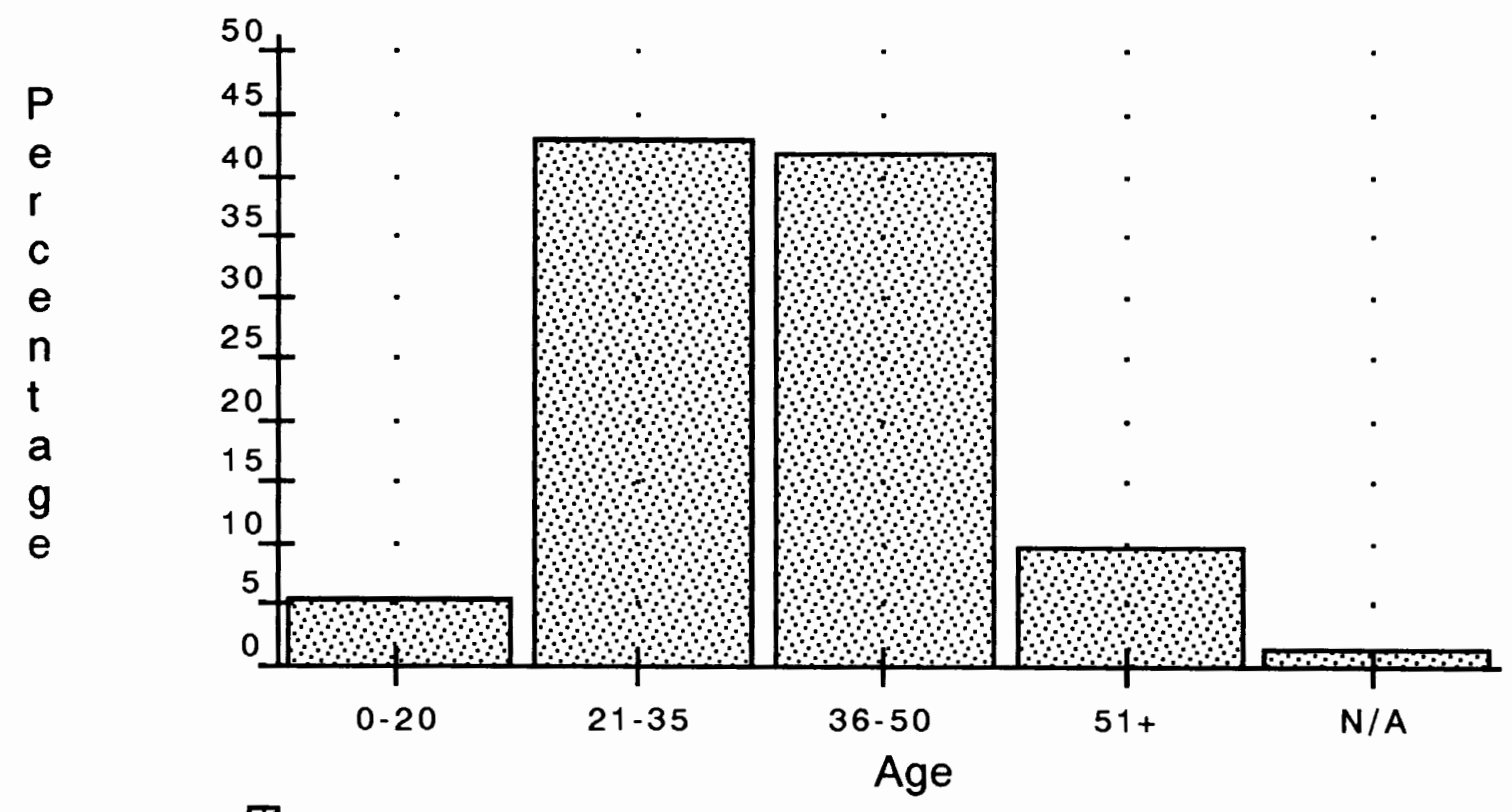

용.95 


\section{Race}

\begin{tabular}{|l|l|l|l|l|l|l|}
\hline & $\begin{array}{l}\text { Amer. } \\
\text { Indian }\end{array}$ & Asian & Black & $\begin{array}{l}\text { His- } \\
\text { panic }\end{array}$ & White & N/A \\
\hline$\#$ & 4 & 4 & 2 & 3 & 163 & 6 \\
\hline 8 & 2.20 & 2.20 & 1.10 & 1.65 & 89.56 & 3.30 \\
\hline
\end{tabular}

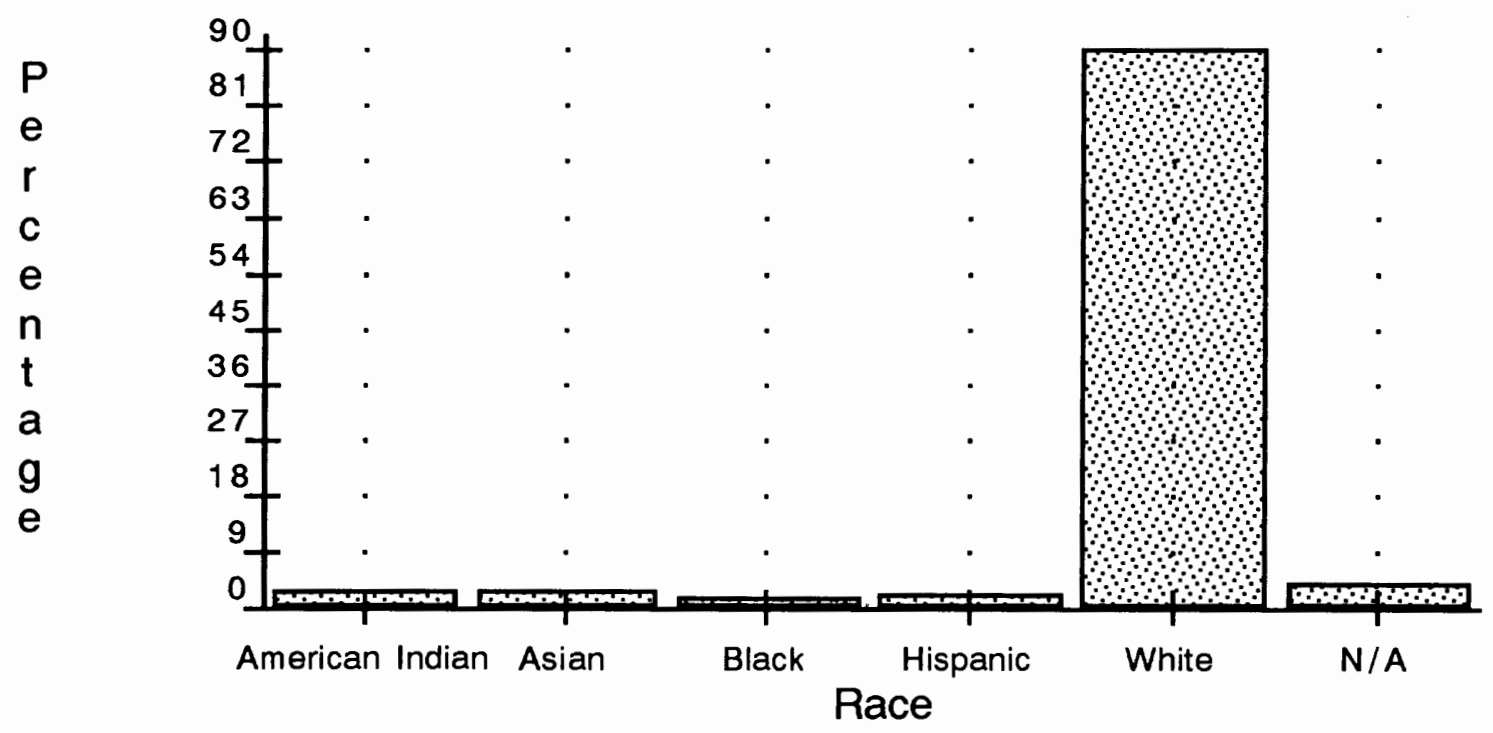

母2.2 
Job Function*

\begin{tabular}{|l|l|l|l|l|l|}
\hline & $\begin{array}{l}\text { New } \\
\text { Accts./ } \\
\text { Cust. } \\
\text { Svc. }\end{array}$ & Teller & $\begin{array}{l}\text { Opera- } \\
\text { tions }\end{array}$ & Lending & No Ans. \\
\hline$\#$ & 49 & 79 & 26 & 19 & 3 \\
\hline 8 & 26.92 & 54.95 & 14.29 & 10.44 & 1.65 \\
\hline
\end{tabular}

* Some participants selected more than one job function

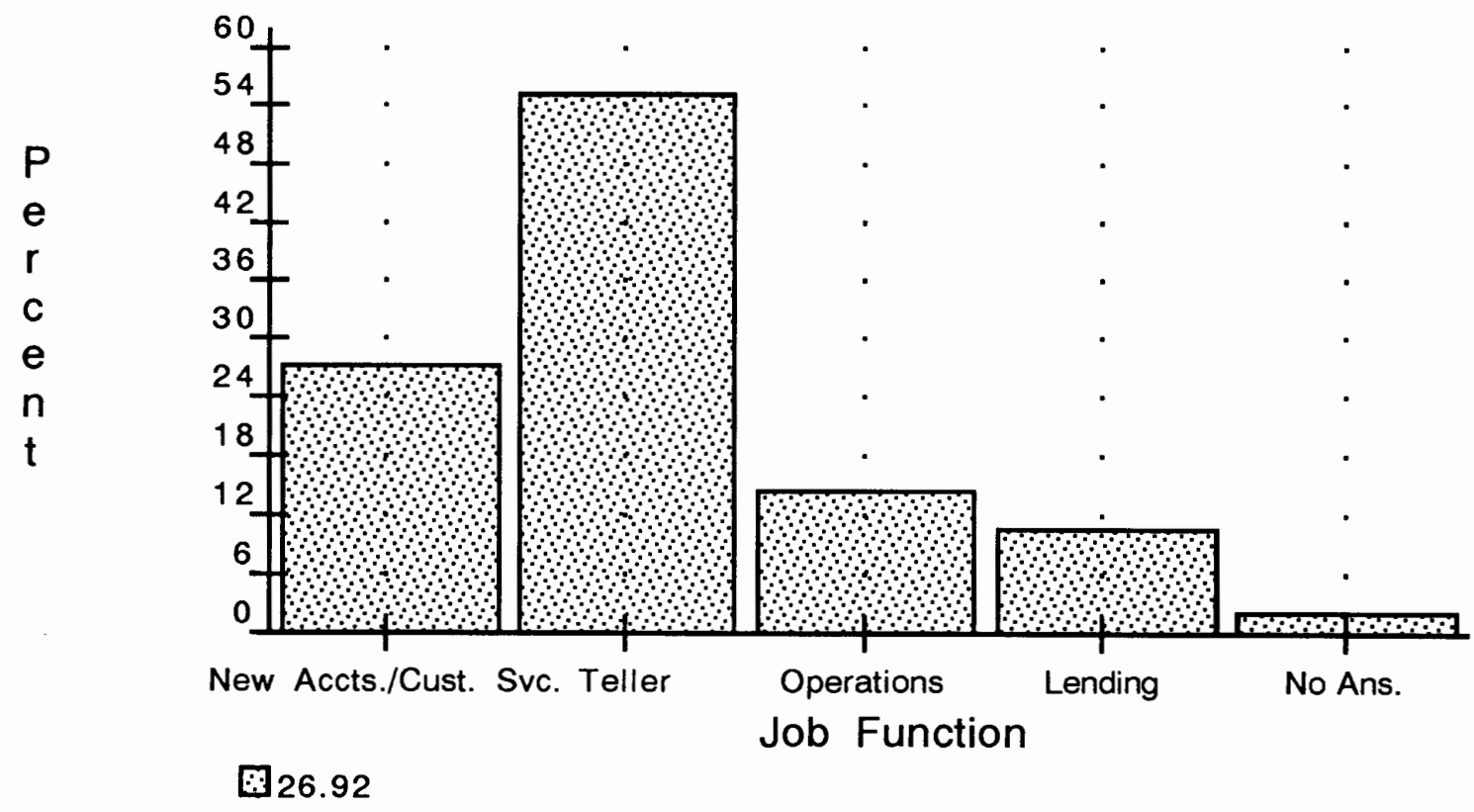




\section{Previous Credit Training}

\begin{tabular}{|l|l|l|l|l|}
\hline & $\begin{array}{l}\text { Very } \\
\text { Iittle } \\
\text { /None }\end{array}$ & Moderate & $\begin{array}{l}\text { Quite a } \\
\text { bit }\end{array}$ & N/A \\
\hline$\#$ & 72 & 72 & 31 & 7 \\
\hline 8 & 39.56 & 39.56 & 17.03 & 3.85 \\
\hline
\end{tabular}

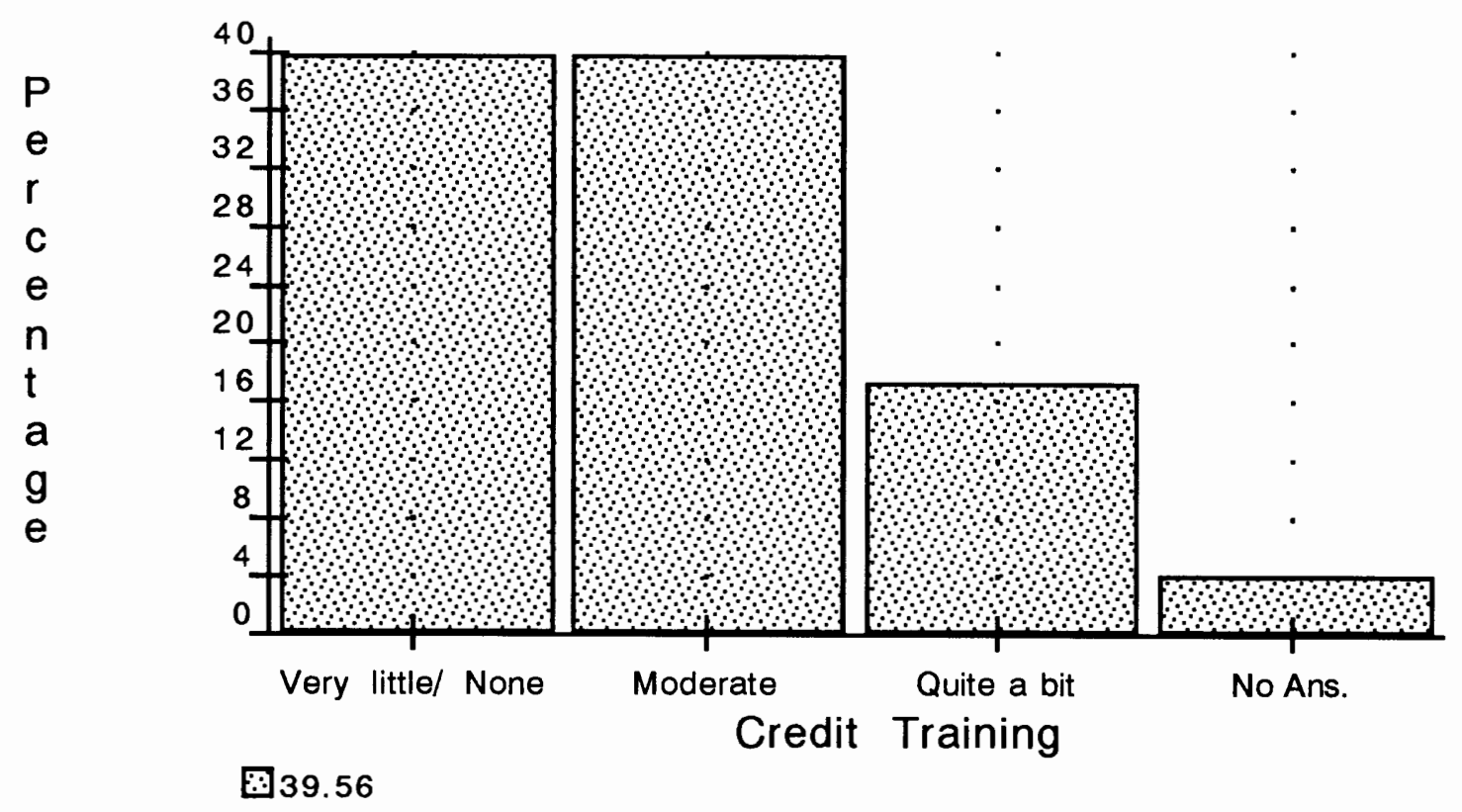


The 5 training methods evaluated in this study were classified in the following groups:

Method 1 Method 2 Method 3 Method 4 Method 5

Control- Video Study Video \& Video,

No Only Guide study study Guide \&

Training Only Guide Reinforcement Mtg.

Participants received the selected training and then completed an assessment containing 22 scorable items (14 questions). Four of the questions asked for more than one answer which accounts for the discrepancy between the number of questions and the number of scorable items. Every correct answer received a score of one. For those questions which asked for multiple answers, each numbered blank line received a score of one if correct; zero if incorrect. All incorrect answers and questions left blank received a score of zero. The maximum score for this assessment was 22 .

An Analysis of Variance statistical procedure (using the statistical software package SYSTAT) was utilized to determine if there was a difference in mean scores for the 5 training methods. The results showed a significant difference between the means at the alpha $=.05$ level of significance when looking at the total sample. This means that some "P ratio" results (listed in tables under columns labeled "P") were less than .05 which implied 
significantly different mean scores between groups. Here are the results of the study.

\section{Table 1}

\section{Cell information}

\begin{tabular}{|l|l|l|l|l|l|}
\hline & $\begin{array}{l}\text { Control } \\
\text { Group } \\
\text { Only }\end{array}$ & $\begin{array}{l}\text { Study } \\
\text { Guide }\end{array}$ & $\begin{array}{l}\text { Video \& } \\
\text { Study } \\
\text { Guide } \\
\text { Study \& } \\
\text { Gide \& } \\
\text { Reinf. } \\
\text { Mtg. }\end{array}$ \\
\hline MALES & & & & & \\
\hline Mean & 14.560 & 16.960 & 19.000 & 14.000 & 18.800 \\
\hline SD & 4.633 & 2.748 & 2.000 & 3.464 & 3.899 \\
\hline FEMALES & 5 & 5 & 3 & 3 & 5 \\
\hline MEan & 12.719 & 14.851 & 15.170 & 16.207 & 16.543 \\
\hline S D & 4.554 & 3.179 & 3.760 & 3.913 & 3.071 \\
\hline n & 26 & 41 & 30 & 29 & 35 \\
\hline
\end{tabular}

The number of male and female participants in each cell was unequal (The number of participants in each training group is indicated in the row labeled "n"). This was due to the randomness of the sample as well as the ratio of males to females in a bank branch environment. This sample was a fair representation of the ratio of males to females in bank branches, so the unequal cell sizes were expected. 
Because the sample was randomly selected and the cell sizes were unequal, systat, which is a true least squares statistical program, used a least squares method within a regression technique to account for the difference in cell size.

\section{TABLE 2}

\section{OVERALL TWO-WAY ANALYSIS OF VARIANCE}

\begin{tabular}{|l|l|l|l|l|l|}
\hline $\begin{array}{l}\text { Source } \\
\text { of } \\
\text { Varia- } \\
\text { tion }\end{array}$ & $\begin{array}{l}\text { Sum-of- } \\
\text { Squares }\end{array}$ & DF & $\begin{array}{l}\text { Mean- } \\
\text { Square }\end{array}$ & F-Ratio & P \\
\hline Training & 162.751 & 4 & 40.688 & 3.055 & 0.018 \\
\hline Sex & 42.994 & 1 & 42.994 & 3.228 & 0.074 \\
\hline $\begin{array}{l}\text { Inter- } \\
\text { action } \\
\text { Training } \\
\text { Sex }\end{array}$ & 56.058 & 4 & 14.014 & 1.052 & 0.382 \\
\hline $\begin{array}{l}\text { Within } \\
\text { Cells }\end{array}$ & 2291.074 & 172 & 13.320 & & \\
\hline
\end{tabular}


TABLE 3

MUTUALLY ORTHOGONAL COMPARISON OF TRAINING

\begin{tabular}{|c|c|c|c|c|c|}
\hline $\begin{array}{l}\text { Source } \\
\text { of } \\
\text { Varia- } \\
\text { tion }\end{array}$ & $\begin{array}{l}\text { Sum-of- } \\
\text { Squares }\end{array}$ & DF & $\begin{array}{l}\text { Mean- } \\
\text { Square }\end{array}$ & F-Ratio & $\overline{\mathbf{P}}$ \\
\hline $\begin{array}{l}\text { Control } \\
\text { Group } \\
\text { vs. } \\
\text { Training }\end{array}$ & 206.638 & 1 & 206.638 & 15.236 & 0.000 \\
\hline $\begin{array}{l}\text { video } \\
\text { vs. } \\
\text { study } \\
\text { Guide }\end{array}$ & 3.682 & 1 & 3.682 & 0.271 & 0.603 \\
\hline $\begin{array}{l}\text { Video } \\
\text { st. } \\
\text { Guide } \\
\text { vs. } \\
\text { video OR } \\
\text { study } \\
\text { Guide } \\
\text { only }\end{array}$ & 11.093 & 1 & 11.093 & 0.818 & 0.367 \\
\hline $\begin{array}{l}\text { video, } \\
\text { study } \\
\text { Guide \& } \\
\text { Mtg. vs. } \\
\text { other } \\
\text { training }\end{array}$ & 48.741 & 1 & 48741 & 3.594 & 0.060 \\
\hline $\begin{array}{l}\text { Within } \\
\text { Cells }\end{array}$ & 2400.638 & 177 & 13.563 & & \\
\hline
\end{tabular}




\section{TABLE 4}

\section{PAIRWISE ANOVA OF CONTROL GROUP VS. TRAINING METHOD}

\begin{tabular}{|l|l|l|l|l|l|}
\hline $\begin{array}{l}\text { Source } \\
\text { Of } \\
\text { Varia- } \\
\text { tion }\end{array}$ & $\begin{array}{l}\text { Sum-of- } \\
\text { Squares }\end{array}$ & DF & $\begin{array}{l}\text { Mean- } \\
\text { Square }\end{array}$ & F-Ratio & P \\
\hline Training & 273.675 & 4 & 68.419 & 5.045 & .001 \\
\hline $\begin{array}{l}\text { Within } \\
\text { Celis }\end{array}$ & 2400.638 & 177 & 13.563 & & \\
\hline
\end{tabular}

TABLE 5

PAIRWISE COMPARISON OF P-VALUES OF CONTROL GROUP VS. TRAINING

\begin{tabular}{|l|l|}
\hline & P-value \\
\hline Video only & 0.112 \\
\hline Study Guide only & 0.052 \\
\hline Video \& Study Guide & 0.011 \\
\hline $\begin{array}{l}\text { Video, St. Guide \& Reinf. } \\
\text { Mtg. }\end{array}$ & 0.000 \\
\hline
\end{tabular}

Table 2 shows that there was a significant difference between mean scores based on training method $(p=.018)$. There was no significant difference between mean scores based on sex $(p=.074)$ or the interaction between training method and sex $(p=.382)$. These results indicate that the training method did impact the participant's ability to recall the 
material. A participant's sex did not impact his/her ability to recall the material, and there was no difference between training method effectiveness based on sex.

Table 3 takes the next step. Table 2 showed that there was a significant difference between training methods, but doesn't show what the actual differences were. Table 3 shows the results of a mutually orthogonal comparison of training methods which determines where the difference(s) occurred. The results indicate that there was a significant difference between mean scores of the control group and the mean scores of the average of the other training methods $(p=.000)$. All other P-values were greater than the maximum alpha $=.05$ level indicating that there were no other significant differences between the mean scores of the various training methods (see Table 3 results under the column labeled "P"). This shows that the participant's ability to recall the material immediately after training was not significantly different due to training method.

Tables 4 and 5 show the results of a pairwise ANOVA. The pairwise ANOVA compared the mean scores of the control group versus each training method individually in order to determine if all four training methods produced significantly different results than no training at all. The results indicated that there was a significant difference between the mean scores of the control group and all training 
methods except video. There was not a significant difference between the mean scores of the video group and the control group. This means that video training by itself was not significantly more effective than having no training at all.based on these analysis

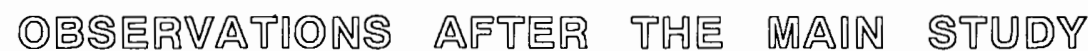

After completing the main study, I chose to address some peripheral questions which might provide additional insight with which to interpret the findings of this study or provide a basis for future studies. These exploratory questions are included in the "Observations After the Main Study" section. I addressed 5 areas of interest: Differences by Sex;

Differences by Training Method; Training Method Effectiveness Ranking; Differences by Age; Differences by Race/National Origin (if sufficient numbers of participants in varying age or race/national origin categories were represented).

\section{DIFFERENCES BY SEX}

As noted in Table 2, the P-value for the differences in mean scores for males and females was 0.074. At an alpha $=.05$, this score was not significant, however, it approached 
the .05 level which indicates that there may be some differences which might be uncovered with a larger sample. For the purposes of this discussion, I will use the mean scores obtained in this study to explore differences by sex.

\section{Table 6}

\section{Male and Female Mean Scores by Group}

\begin{tabular}{|l|l|l|l|l|l|}
\hline & $\begin{array}{l}\text { Control } \\
\text { Group }\end{array}$ & $\begin{array}{l}\text { Video } \\
\text { Only }\end{array}$ & $\begin{array}{l}\text { Self- } \\
\text { Study } \\
\text { Only }\end{array}$ & $\begin{array}{l}\text { Video \&elf- } \\
\text { Study }\end{array}$ & $\begin{array}{l}\text { Video \& } \\
\text { Self- } \\
\text { Study \& } \\
\text { Meeting }\end{array}$ \\
\hline $\begin{array}{l}\text { Male } \\
\text { Scores }\end{array}$ & 14.560 & 16.960 & 19.000 & 14.000 & 18.800 \\
\hline $\begin{array}{l}\text { Female } \\
\text { Scores }\end{array}$ & 12.719 & 14.851 & 15.170 & 16.207 & 16.543 \\
\hline
\end{tabular}

Table 6 shows the mean scores for males and females by training method. Even though the differences between mean scores of males and females by training method were not significant in the ANOVA test, the mean scores do show male and female differences by method. In all cases except the video plus self-study group, the mean scores for the males were higher than the females.

A breakdown of demographic information by sex was completed to determine if other factors may have influenced the differences in scores based on sex. The following graphs depicting demographic information show that the differences may be attributed to other factors. 


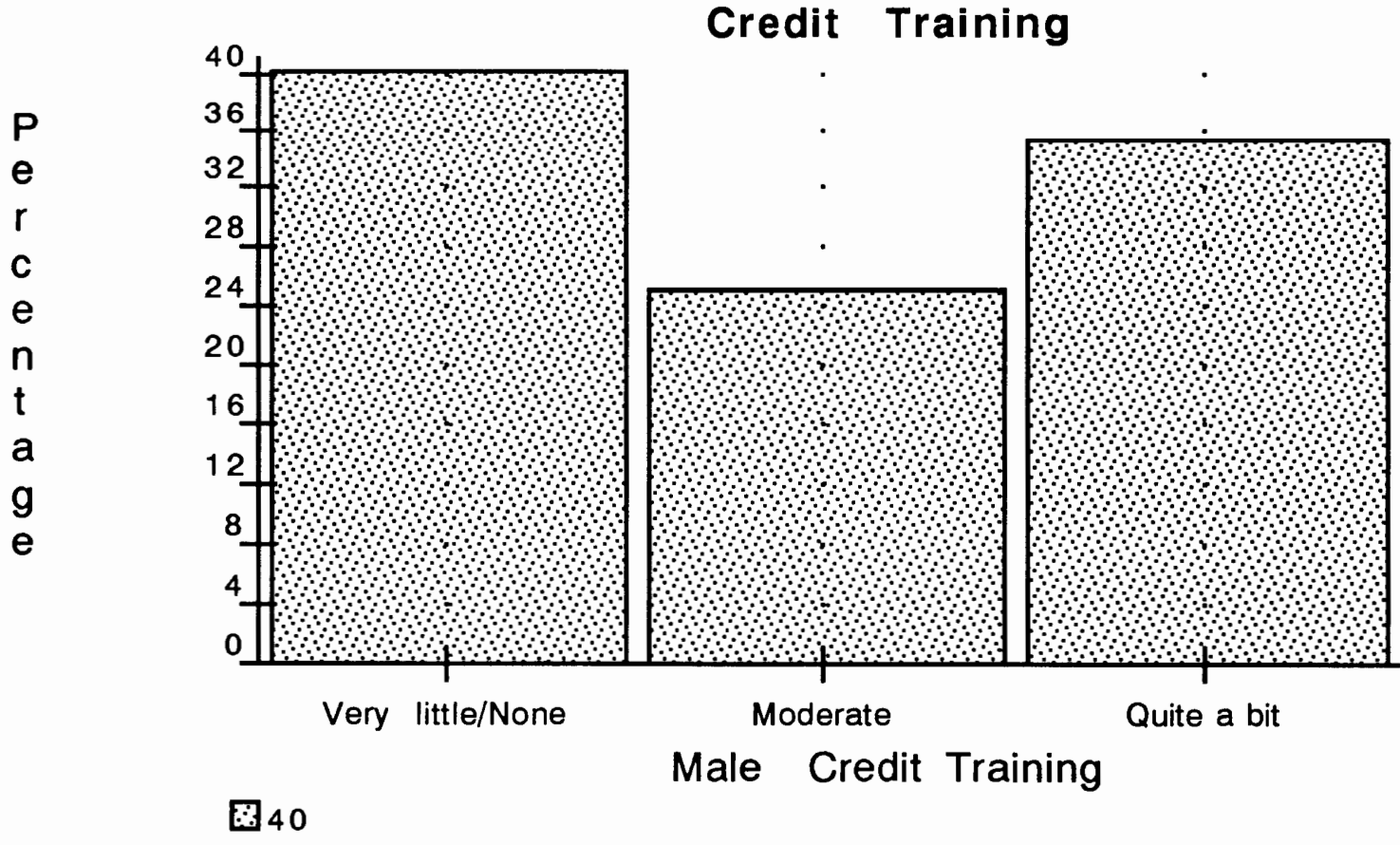

$P$
$e$
$r$
$c$
$e$
$n$
$t$
$a$
$g$
$e$

\section{Credit Training}

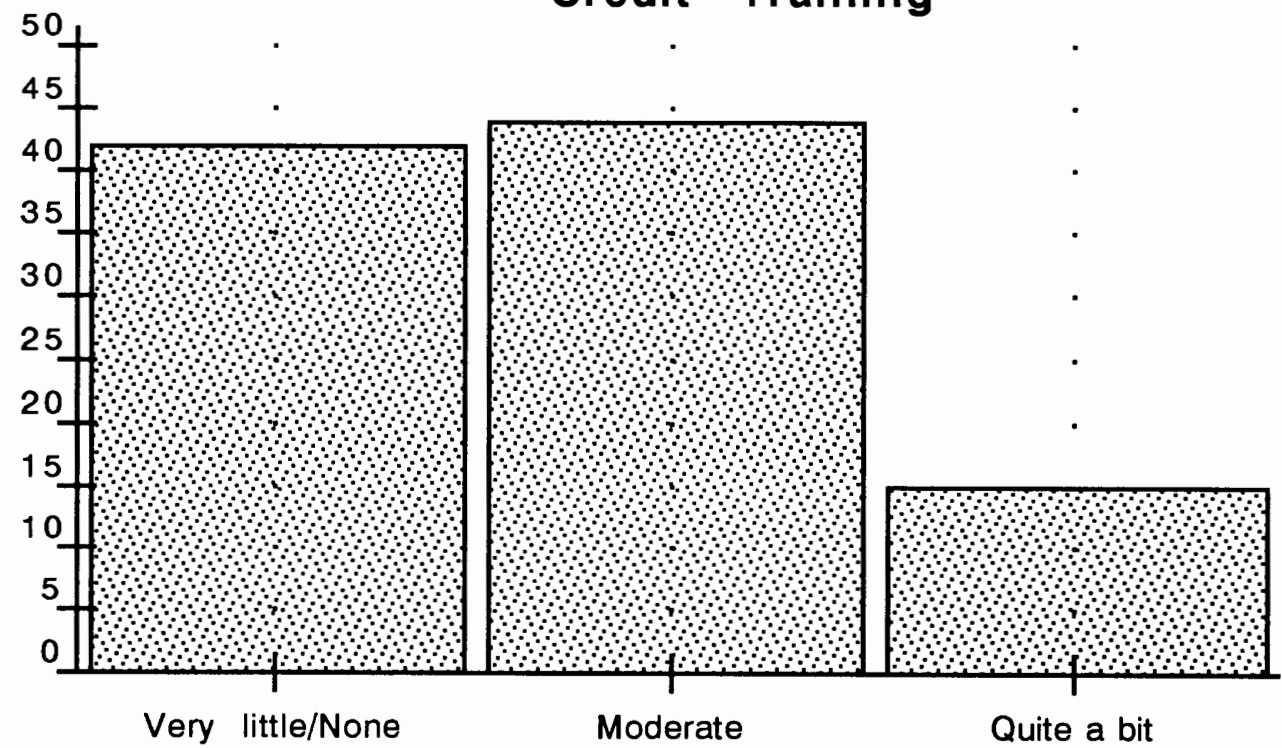

母4.666

Female Credit Training 


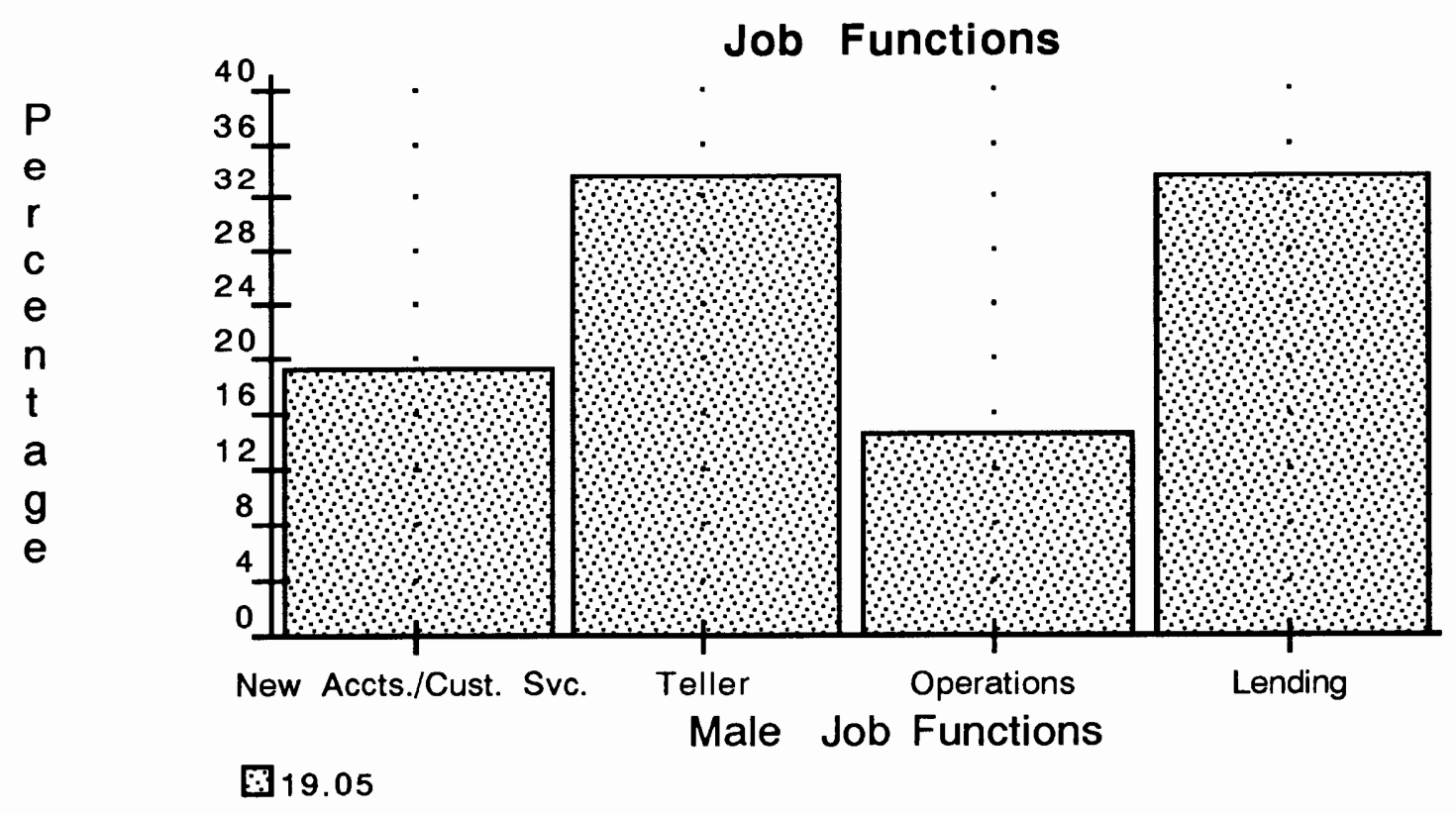

$P$
$e$
$r$
$c$
$e$
$n$
$t$
$a$
$g$
$e$

Job Functions

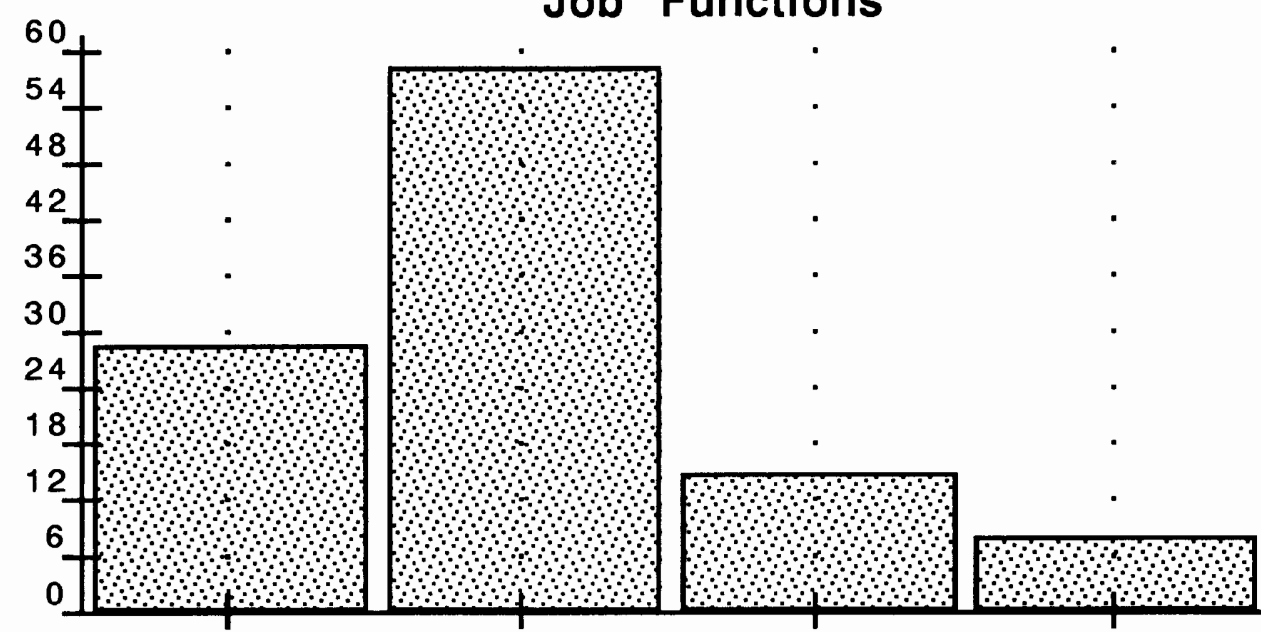

New Accts./Cust. Svc.

Teller

Operations

Lending

Female Job Functions

$\$ 27.95$ 
The charts show that male participants held more senior positions (lending and operations) and had more credit training than females. The product which was trained and tested was a credit related product; a product not sold by tellers. Tellers have not received as much credit training as the other job functions. One additional factor which may have influenced the scores was that the branch managers knew about the study, facilitated the training, and were asked to participate by completing an assessment as well. Ten out of twenty managers were male, so up to 10 out of the 21 males who participated may have had prior knowledge of the study, and paid more attention than normal to the training.

\section{DIFFERENCES BY TRAINING METHOD}

Table 3 outlined results which indicated that a significant difference in mean scores at the .05 level existed between the control group and the other training methods $(p=.000)$, but not between the training methods themselves. Once again we find a p-value approaching the .05 level on this table. The video \& study guide \& reinforcement meeting vs. other training methods comparison produced a p-value of 0.060 . That implies that there might be some differences between the effectiveness of the video, study guide plus meeting training and the other training methods which might be uncovered with a larger sample size. 
The pairwise ANOVA was completed to determine if the mean scores of the individual training methods were significantly different than the control group mean scores. Table 4 and 5 outlined the results. The only method which did not show a significant difference in mean scores from the control group was video. This indicated that video training was not significantly more effective than no training based on these analysis.

\section{TRAINING METHOD EFFECTIVENESS RANKING}

When comparing the effectiveness (based on post-training assessment scores) of the 5 training methods, it is important to note that in the mutually orthogonal comparison ANOVA (Table 3) all methods showed significant differences in mean scores from the control group. The most comprehensive method, video \& study guide \& reinforcement meeting, had a pvalue of 0.06 (slightly higher than the p-value limit of $.05)$. In the pairwise ANOVA (Table 5), study guide only, video plus study guide, and video, study guide plus reinforcement meeting showed significantly different scores than the control group. Video scores were not significantly different than the scores of those who had no training. The results from both ANOVA tests show that study guide, video \& study guide, and video \& study guide \& reinforcement meeting training methods are more effective than no training. 
The ANOVA results did not provide a ranking of most effective to least effective training methods. However, an effectiveness ranking is useful when determining how to design the best training for a branch environment. In order to determine an effectiveness ranking, I looked at 3 measures: pairwise p-value, mean score, and p-value by question. I then ranked the groups by each measure, compared the scores and determined the effectiveness rating. The rating scale was as follows: 1 = most effective; 5 = least effective.

\section{Table 7}

\section{Pairwise P-value}

\begin{tabular}{|l|l|l|}
\hline & $\begin{array}{l}\text { Pairwise P-value } \\
\text { (comparison to } \\
\text { control group) }\end{array}$ & Ranking \\
\hline 1) Control Group & ---- & 2 \\
\hline 2) video & .112 & 2 \\
\hline 3) Study Guide & .052 & 1 \\
\hline $\begin{array}{l}\text { 4) Video \& Study } \\
\text { Guide \& Study }\end{array}$ & .011 & 1 \\
\hline $\begin{array}{l}\text { Video \& Meeting } \\
\text { Guide \& }\end{array}$ & .000 & 1 \\
\hline
\end{tabular}

*(Data in column taken from table 5, and included in this table for ease of comparison only.)

In this measure I determined that there were only 2 possible ranks, \#1 and \#2. Methods 3,4 and 5 received a ranking of 1 , because their mean scores were all significantly 
different from the control group mean scores. Method 2 mean scores were not significantly different from the control group mean scores giving method two a ranking of 2 .

\section{Table 8}

\section{Mean Score}

\begin{tabular}{|l|l|l|}
\hline & Mean Score & Ranking \\
\hline Control Group & 13.016 & 5 \\
\hline Video & 15.080 & 4 \\
\hline Study Guide & 15.518 & 3 \\
\hline $\begin{array}{l}\text { Video \& Study } \\
\text { Guide \& Study }\end{array}$ & 16.000 & 2 \\
\hline $\begin{array}{l}\text { Video \&uide \& } \\
\text { Reinforcement } \\
\text { Mtg. }\end{array}$ & 16.825 & \\
\hline
\end{tabular}

When comparing mean scores, a clear ranking is possible. The ranking was determined as follows: the higher the mean score; the higher the ranking.

An analysis of variance procedure was performed comparing the mean scores of the 5 methods question by question. Out of the 14 questions, 5 showed significant differences between groups. In 808 of the significant cases, there were not only differences between the mean scores of the control 
group and the mean scores of the training groups individually, but also between the mean scores of each of the training groups. Table 9 lists only those results which were significant question by question.

Table 9

Questions with significant differences in the mean scores for the 5 groups

\begin{tabular}{|l|l|l|l|l|l|l|l|l|}
\hline & Q1 & Q1 & $Q 5$ & $Q 5$ & $Q 9$ & $Q 9$ & $Q 13$ & Q15 \\
\hline Method & $C G$ & $S G$ & $C G$ & $S G$ & $C G$ & $V$ & $C G$ & $V$ \\
\hline V & & & .000 & & & & .000 & \\
\hline S G & & & & & .001 & .001 & .024 & \\
\hline $\begin{array}{l}\text { V \& } \\
\text { S G }\end{array}$ & & & .011 & & .006 & .005 & .001 & \\
\hline $\begin{array}{l}\text { V \& } \\
\text { SG \& } \\
\text { RM }\end{array}$ & .001 & .034 & .000 & .006 & .000 & .000 & .014 & .019 \\
\hline
\end{tabular}

Table 9 indicates the following patterns:

1) On all questions listed in Table 9, the video \& study guide \& meeting method showed significantly different mean scores than the other methods listed (see V\& SG\& RM row). When reviewing actual answers by training method 
per question, the video \& study guide \& meeting method produced more correct answers.

2) The video plus study guide method showed the next most significant differences in mean scores. As noted in the $\mathrm{V}$ \& SG row, the video plus study guide method produced significantly different mean scores from the control group on questions 5, 9 and 13, and significantly different mean scores from the video only method on question 13.

3) The study guide only method was next in line with 3 significantly different mean scores from other methods on questions 9 and 13. The study guide only method showed significantly different results from the control group mean scores on question 9 and 13, as well as different results from the video only method on question 9.

4) The video only method showed the least significant differences of all the methods. This method only showed significant differences in mean scores from the control group. The results are shown in row $\mathrm{V}$ under questions 5 and 13 .

Table 10 lists the ranking of training methods based on the table 9 results and discussion following table 9. 


\section{P-value by Question ranking}

\begin{tabular}{|l|l|}
\hline & Ranking \\
\hline Control Group & 5 \\
\hline Video & 4 \\
\hline Study Guide & 3 \\
\hline Video \& Study Guide & 2 \\
\hline Video \& Study Guide \& Mtg. & 1 \\
\hline
\end{tabular}

Comparing the 3 measures (pairwise p-value, mean score, and p-value by question), a clear ranking emerges. Once again, according to the pairwise ANOVA results, there is only a significant difference between the mean scores of the control group and study guide, video \& study guide, and video \& study guide \& meeting. According to the mutually orthogonal ANOVA, a significant difference exists between the mean scores of the control group and the other methods The video \& study guide \& meeting had a P-value of 0.06 in the mutually orthogonal ANOVA. Table 11 outlines the rankings which were determined from the results listed in Tables 7,8,9 and 10 and discussed following each table. 
Overall Training Method Effectiveness Ranking

\begin{tabular}{|l|l|l|l|}
\hline & $\begin{array}{l}\text { P-value } \\
\text { Ranking }\end{array}$ & Mean Ranking & $\begin{array}{l}\text { P-value/Q } \\
\text { Ranking }\end{array}$ \\
\hline $\begin{array}{l}\text { Control } \\
\text { Group }\end{array}$ & 2 & 5 & 5 \\
\hline Video & 2 & 4 & 4 \\
\hline Study Guide & 1 & 3 & 3 \\
\hline $\begin{array}{l}\text { Video \& } \\
\text { Study Guide }\end{array}$ & 1 & 2 & 2 \\
\hline $\begin{array}{l}\text { Video \& } \\
\text { Study Guide } \\
\text { \& Mtg. }\end{array}$ & 1 & 1 & 1 \\
\hline
\end{tabular}

When comparing the mean scores, the Pairwise ANOVA results on the total sample, and the ANOVA results on a per question basis, the method effectiveness can be ranked as follows (1=most effective; $5=$ least effective) :

\begin{tabular}{|c|l|}
\hline Rank & $\mid$ \\
\hline 1 & $\begin{array}{l}\text { Video \& Study Guide \& } \\
\text { Reinforcement Meeting }\end{array}$ \\
\hline 2 & Video \& Study Guide \\
\hline 3 & Study Guide \\
\hline 4 & Video \\
\hline 5 & Control Group--No training \\
\hline
\end{tabular}

This analysis indicates that the more training methods utilized (to the extent of this analysis), the better the short term material recall. 


\section{Age}

The question of how age impacts the effectiveness of the training methods was researched as well. An ANOVA was conducted and the results showed that there was no significant difference in the mean scores for the 5 methods based on age.

\section{Race/National Origin}

An ANOVA was not completed on race/national origin due to the limited number of participants in classifications other than white, non-hispanic. 
This study was conducted in order to compare the effectiveness of 4 training methods which were designed to be used in a bank branch environment. A control group was used to determine a pre-training baseline making a total of 5 groups. The methods reviewed did not require a skilled training facilitator, and were either individualized or selfstudy training, or were branch reinforcement sessions conducted during regularly scheduled staff meetings by a branch representative. The design of the training methods addressed the constraints voiced by training managers that training must be quick, inexpensive, not disruptive of branch operating procedures, and still be effective.

The results showed that there was a significant difference between the mean scores of the control group and the mean scores of the following groups: study guide only, study guide plus video, and study guide, video, plus reinforcement meetings. The video only and control group mean scores were not significantly different based on these analysis. There were no significant differences between the mean scores of the four training methods.

When researching training effectiveness based on sex, the results showed that there was no significant 
difference between mean scores of males and females. There was also no significant difference in method effectiveness based on sex.

A comparison of the results of this study to the results of the studies cited in this document was completed. This study's results support some findings, contradict others, and suggest that some traditional training methods may be less effective than advertised to be. A discussion of the most significant findings is included below.

Multiple references in the literature review stated that people learn differently, people benefit from using a variety of methods, or people have different learning styles. This research supports those findings. When looking at individual survey results, it can be noted that there were high scores in each group. The video only group had the least high scores and the video, study guide plus reinforcement meeting had the most high scores. The greater the number of training methods used and the greater the participation required on the part of the student, the higher the mean scores.

Knowles (1973) states that adults need to be actively involved in their training for it to be effective. This study supports his findings. Video only was the one method which did not require active involvement by the participants and it was the only method which did not improve 
mean scores significantly over the control group mean scores according to the pairwise ANOVA.

This study does not support Gagliano's (1988) findings that video training increased short term knowledge or Stalonas', et al. (1979) findings that when comparing video, live lecture and written training methods, videotape students scored higher than other methods. Although the methods studied did not show significant differences between mean scores, the video only mean score was the only score which was not significantly different from the control group mean according to the pairwise ANOVA. This would indicate that video only was not more effective than the other methods and did not significantly increase short term knowledge based on these analysis. When reviewing the actual mean scores for the 4 training methods, the mean score for the video only was the lowest mean score of all the methods studied.

Osguthorpe, et al. (1983) found that no significant differences existed between video, video and written, written only, and regular inpatient instruction. Murphy (1977) says few, if any, differences exist between training methods. This study found the same results overall. When reviewing the results on a question by question basis there were significant differences by training method, however, when looking at the overall results, there were no significant differences between methods. 


\section{ADDITIONAL RESEARCH OPPORTUNITIES}

There are opportunities for additional research relating to this study.

1) This study tested short term material recall. Testing to see which method provides better long term material recall would uncover better on-the-job product knowledge retention training.

2) The survey was designed to test items which were covered in every training method used. Only 5 of the 14 questions showed significant differences between the participant's ability to answer based on group (see table 9). Most other questions appeared to test "common knowledge" in a branch environment. The surveys would better test training effectiveness if the training covered (and the surveys tested) new information, or if only new employees participated in the research.

3) The male/female distribution in a bank branch environment was accurately represented by this sample. Due to the small sample of male participants coupled with the factors described in the Observations After The Main Study section which may have influenced the scores, the differences in training effectiveness could be reexamined. A male sample equal to the female sample in size and experience 
level, which has not been informed about the survey prior to the training might yield different results.

4) Two additional measures which could be explored further are group effectiveness based on age and group effectiveness based on race/national origin. In this study an ANOVA was completed on group effectiveness based on age and no significant difference in mean scores was found between age categories. Even though the age distribution was a good representation of a branch environment, an even distribution of participants in each age category, may have yielded different results.

The sample in this study was comprised of employees in randomly selected branches. In the branches selected, 898 of the participants were white, non-hispanic people. If the sample had a more even representation of other races/national origins, an ANOVA studying method effectiveness based on race/national origin could be completed.

\section{STUDY LIMITATIONS}

After evaluating the results of this study, I noted two major limitations. First, the research assistants participated in the study. They were asked to participate, because 
ten of the assistants were males, and excluding them from the study would have reduced our male sample to 11 . With that small of a male sample, no male/female comparison could have been done. They were also asked, because all assistants were managers. Their participation reinforced the message that all branch personnel were taking part in the study, and no one would be checking the employees' scores.

The problem with including the assistants' scores was that they knew about the research prior to completing the training. They had the opportunity, and knew the benefits of paying closer attention to the training than normal which could have positively impacted their scores. The manager's assessments were not identified, so isolating their scores from the results was not possible. The research assistants' scores could have influenced the results. A further study would seek a sample more representative of employees subject to training.

The second limitation relates to two variables which were not examined in-depth, but could have provided some additional insight into the study findings. Those variables were credit training and job function. Comparing the interaction of credit training and/or job function to the training methods may have showed that the type of previous training or experience impacted an employees' ability to learn from different training methods. If a significant 
interaction was discovered, it might have impacted the finding that video training did not produce significantly different results than the control group, or identified significant differences between the methods based on previous training or job function.

\section{CONCLUDING COMMENTS}

This study was a worthwhile process which supported other research in the area of training methodology, and seemed to provide some additional findings which other research failed to uncover. First of all, the study showed that most training does make a difference. Training can improve short term material recall. The study also showed that overall, the methods reviewed did not produce significantly different mean scores. This result indicates that none of the four methods were significantly more effective than the other methods (although the video, study guide plus reinforcement meeting method came close with a .06 p-value). All these results support findings in other studies.

This study went on to look beyond the mutually orthogonal comparisons to explore pairwise comparisons. This additional comparison was not discussed in any of the other studies I reviewed. The results showed that participants who utilized the video only method of training produced mean 
scores which were not significantly different from those participants who received No training. Those findings indicated that although the mean scores of the four methods were not significantly different, the video only method (which had the lowest mean score of all the methods) was the least effective method as measured by short term material recall (post-training assessment scores). It could also be said that video training is not a significantly effective method of training for short term material recall based on the pairwise results (the video only method mean scores were not significantly different than control group means).

These findings are important to note because, according to Training Magazine, 88.78 of the companies they surveyed use video based training, and Lakewood Research's study showed that 83.28 of US companies with 50 or more employees use videotape. The results and analysis completed in this study suggest that although videotape training is quick, relatively inexpensive when compared to other training methods, and less disruptive than some other methods, stand alone video training may not significantly impact short term knowledge. In order to significantly impact short term knowledge, these results suggest that combining video with some form of training which requires active participation from the student or just using a study guide alone will be more effective at increasing short term knowledge and be a better return on the training investment than video alone. The results 
further showed that adding two participative training modules to a video presentation, would enhance training effectiveness to a greater degree.

This research also provided results which made it possible to rank the effectiveness of 4 methods of training. Limiting the research process to one series of ANOVA tests without a more in-depth look at how all the results interrelate would not have provided a framework from which to select the most effective training methods. Without the effectiveness ranking information, this research would have stopped short of providing valuable practical input into the training design process. As it is, the study answered a full range of questions from, "Is training effective?" to "Which training method is most effective in a branch environment?", and, as always, brought up quite a few more questions which beg to be explored. I think I'll wait until next time. 
APPENDIX 1

PRODUCT KNOWLEDGE TRAINING SURVEY 
Appendix 1

\section{Product Knowledge Training Survey}

Completion of this Product Knowledge Training survey is voluntary. The results of this training survey will be used in a research study to evaluate training methods. Your name and branch are not requested, and your responses will be kept confidential. Your score will not be traced back to you, and will in no way impact your job.

\section{Part I}

Number of Years/Months in banking

Number of Years/Months in current job

Job Function

New Accounts/Customer svc. Operations

Teller

Lending

Sex

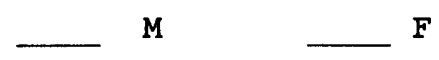

Age

$0-20$

$21-35$

$36-50$

$51+$

Previous Credit Training

Very little/none Moderate amount

Race/National origin

$$
\text { Quite a bit }
$$

American Indian or Alaskan Native Asian or Pacific Islander

Black, not of Hispanic origin

Hispanic

White, not of Hispanic origin

Is English your primary/first language? yes no

Part II

NOTE--If you are not sure of the answer, feel free to leave the question blank.

1) What interest rate index is used for all Advancelines?

2) What are 2 customer benefits which are unique to an Advanceline secured with a customer's home?

A) 
B)

3) How do customers access Advanceline funds?

4) What type of interest is charged on Advancelines?

5) What can be used as collateral for an Advanceline?

A)

C)

6) For what purposes can customers use Advanceline funds?

7) What are the Advanceline repayment options?

A)

B)

C)

8) Why do we say that Advanceline has less paperwork?

9) Name the types of Advancelines we offer.

A)

C)

10) Why might someone who has ongoing borrowing needs choose an Advanceline?

12) How often can a customer access Advanceline funds?

13) How often is the interest rate adjusted?

14) What does (BANK) do to protect customers from high variable rates on Advancelines secured by a customer's home?

15) If a customer has $\$ 50,000$ equity in his/her home and wants to borrow, would an Advanceline or Installment Loan be best? 


\section{APPENDIX 2}

\section{MEMO TO BRANCH REPRESENTATIVES}

TWO VERSIONS 
Appendix 2

MEMO TO BRANCH REPRESENTATIVES--TWO VERSIONS

Memo to: Branch Manager

Subject: Training Research Project

Date: $\quad 3-4-94$

Your branch has been randomly selected to assist in a research project for the training department. Many other branches will take part in this research as well. The results of this research may impact training design for the entire corporation system-wide, so precisely following the outlined instructions is essential to providing accurate data.

The training department is researching the effectiveness of a variety of current in-branch training methods. Those branches who have been selected to participate in the research will conduct a regular training staff meeting using a specific, assigned training method. After the training has taken place, all staff members will be asked to complete a product knowledge training survey. The completed surveys will be sent to an independent researcher who will compile the results for the training department. Your branch will not be identified and the employees names will not be obtained, so the results will not be tracked back to employees or the branch.

The training method your branch will use was also randomly assigned. Your branch will be conducting an Advanceline training session using the following method:

\section{LIST METHOD}

Included in this small envelope is the sheet of instructions for conducting the research. We will review these instructions step-by-step during our March 15th teleconference.

Also included in this packet is a large envelope which says "DO NOT OPEN..." DO NOT OPEN THIS PACKET UNTIL YOU ARE STANDING IN FRONT OF YOUR STAFF DURING THE MEETING. The instruction sheet will give you the meeting order which lists the specific time to open the envelope and distribute the surveys. 
If you are unable to attend the tele-conference, please contact BRANCH REPRESENTATIVE as soon as possible to set up a one-on-one tele-conference with the researcher to talk through the research process, review the instructions, and answer any questions you have.

You are the only person in this branch who knows about this research. Please DO NOT TELL ANYONE ELSE at your branch or discuss with anyone outside your branch. This will help ensure that the results are not biased.

Please hold onto the shrink wrapped meeting kit. You will using one or more components of this kit, but it is essential that none of the components are reviewed by any staff member prior to the training and completion of the surveys.

Thank you for your participation. Once again, your involvement in this this research may impact the design of future training programs throughout all of (BANK).

Memo to: Branch Manager

From: $\quad$ BANK REPRESENTATIVE

Subject: Training Research Project

Date: $\quad 3-4-94$

Your branch has been randomly selected to assist in a research project for the training department. Many other branches will take part in this research as well. The results of this research may impact training design for the entire corporation system-wide, so precisely following the outlined instructions is essential to providing accurate data.

The training department is researching the effectiveness of a variety of current in-branch training methods. Those branches which have been selected to participate in the research will conduct a regular training staff meeting using a specific, assigned training method. After the training has taken place, all staff members will be asked to complete a product knowledge training survey. The completed surveys will be sent to an independent researcher who will compile the results for the training department. Your branch will not be identified and the employees names will not be 
obtained, so the results will not be tracked back to employees or the branch.

The training method your branch will use was also randomly assigned. You will receive a packet in the next couple of days marked "PERSONAL/CONFIDENTIAL". The packet will contain a letter informing you what method you will use, an envelope with red lettering which says "DO NOT OPEN...", a list of instructions for conducting the research, and a shrink wrapped training kit.

The instruction sheet takes you step-by-step through the research process. It also lists the specific time to open the envelope marked "DO NOT OPEN..." and distribute the surveys.

When you receive your packet, please read the instruction sheet, and then call RESEARCHER (the independent researcher working on this project) at PHONE \#. She will give you the specific details of the research process, review the instructions for your training method, and answer any questions you may have.

Please hold onto the shrink wrapped meeting kit. You will using one or more components of this kit, but it is essential that none of the components are reviewed by any staff member prior to the training and completion of the surveys.

You are the only person in this branch who is aware of this research. Please DO NOT TELL ANYONE ELSE at your branch or discuss with anyone outside your branch. This will help ensure that the results are not biased.

Thank you for your participation. Once again, your involvement in this this research may impact the design of future training programs throughout all of (BANK). 
APPENDIX 3

RESEARCH PROCEDURES 
Appendix 3

RESEARCH PROCEDURES

NO TRAINING/CONTROL GROUP INSTRUCTIONS

1) Call staff meeting to order.

2) Read this announcement as written:

Our branch has been randomly selected to participate in a training method effectiveness study. We have been asked to complete a survey which will indicate product knowledge prior to training. We will not be giving our names. This branch will not even be identified, so your score will not be traced back to you and will not impact your job in any way. No one in this branch, the area, the region or this bank will ever see or be notified of your score. It is not mandatory that you complete this survey, however, your participation will enable the training department to develop the most effective training for a branch environment.

3) Describe the process as written:

*I will pass out the surveys.

* Please complete part 1 and part 2 of the surveys to the best of your ability. If you do not know an answer, feel free to leave the answer blank.

*When you have completed the survey, fold it, and put your survey in this envelope (hold up large, addressed mailing envelope.)

* When all surveys have been collected, the envelope will be sealed and sent to an independent researcher.

*Again, no one at this bank will ever see your score.

*All branch employees, including myself, are being asked to participate. I haven't even seen the survey.

* There are many other branches participating in this survey as well.

*Please DO NOT DISCUSS THIS SURVEY WITH ANYONE OUTSIDE THIS BRANCH. This will ensure that the researchers get an accurate assessment of normal training effectiveness. If people know about the survey prior to receiving training, they may pay more than normal attention to training which will distort the findings. 
4) Open envelope in front of staff and pass out surveys.

5 ) After all the completed surveys have been collected in the return envelope, put extra surveys in the envelope as well, seal it and mail with your regular outgoing mail.

6) Do not review completed surveys prior to mailing. Employees were promised verbally and in writing that no one at the bank would see their results.

If you have ANY questions, please call RESEARCHER at PHONE \#. THANK YOU SO MUCH FOR ASSISTING WITH THIS IMPORTANT RESEARCH PROJECT!

\section{VIDEO ONLY INSTRUCTIONS}

REMEMBER TO CONDUCT THE MEETING THE SAME AS YOU NORMALLY WOULD

1) Call meeting to order.

2) Say "We're going to start right off watching a video about our Advanceline product."

3) DO NOT ask employees to pay particular attention to the video or indicate that they will be given a survey after the video. If this is done, the survey results will be distorted.

4) After viewing the video, read this announcement as written:

Our branch has been randomly selected to participate in a training method effectiveness study. We have been asked to complete a survey which will indicate product knowledge after watching a video on the product. We were not told about the survey prior to watching the video, so our scores will represent the normal product knowledge level after watching a 
video. We will not be giving our names. This branch will not even be identified, so your score will not be traced back to you and will not impact your job in any way. No one in this branch, the area, the region or this bank will ever see or be notified of your score. It is not mandatory that you complete this survey, however, your participation will enable the training department to develop the most effective training for a branch environment.

5) Describe the process as written:

*I will pass out the surveys.

*Please complete part 1 and part 2 of the surveys to the best of your ability. If you do not know an answer, feel free to leave the answer blank.

*When you have completed the survey, fold it, and put your survey in this envelope (hold up large, addressed mailing envelope.)

*When all surveys have been collected, the envelope will be sealed and sent to an independent researcher.

*Again, no one at this bank will ever see your score.

*All branch employees, including myself, are being asked to participate. I haven't even seen the survey.

* There are many other branches participating in this survey as well.

*Please DO NOT DISCUSS THIS SURVEY WITH ANYONE OUTSIDE THIS BRANCH. This will ensure that the researchers get an accurate assessment of normal training effectiveness. If people know about the survey prior to receiving training, they may pay more than normal attention to training which will distort the findings.

6) Open envelope in front of staff and pass out surveys.

7) After all the completed surveys have been collected in the return envelope, put extra surveys in the envelope as well, seal it and mail with your regular outgoing mail.

8) Do not review surveys prior to mailing. Employees were promised verbally and in writing that no one at the bank would see their results.

If you have ANY questions, please call RESEARCHER at PHONE \#. 
THANK YOU SO MUCH FOR ASSISTING WITH THIS IMPORTANT RESEARCH PROJECT!

\section{COMMON CONSUMER LOAN PRODUCT'S MAGAZINE ONLY INSTRUCTIONS}

\section{ONE WEEK PRIOR TO THE STAFF MEETING}

1) Hand out Common Consumer Loan Product's Magazine one week prior to staff meeting.

2) Ask staff to complete the Advanceline chapter prior to staff meeting.

3) DO NOT emphasize that employees should pay particular attention to this chapter in any way, otherwise the results will not track normal training effectiveness.

\section{THREE DAYS PRIOR TO THE STAFF MEETING}

Post a sign on a bulletin board which says:

"Staff meeting on (Date)

(Remember to complete the Advanceline chapter of your Common Consumer Loan Product's Magazine prior to the meeting.)

\section{MEETING DAY}

REMEMBER TO CONDUCT THE MEETING THE SAME AS YOU NORMALLY WOULD

\section{1) Call meeting to order.}

2) Ask employees to put away their Common Consumer Loan Product's Magazine. DO NOT allow them to review them even briefly before putting the magazine away. Be sure no one refers to their magazine while completing the survey.

3) Read this announcement as written:

Our branch has been randomly selected to participate in a training method effectiveness study. We have been asked to complete a survey which will indicate product knowledge after completing the magazine only. We were not told about the survey prior to completing the magazine on purpose, so our scores will represent the normal product knowledge level after self-study. We will not be giving our names. This branch will not even be identified, so your score will not be traced back to you and will not impact your job in 
any way. No one in this branch, the area, the region or this bank will ever see or be notified of your score. It is not mandatory that you complete this survey, however, your participation will enable the training department to develop the most effective training for a branch environment.

4) Describe the process as written:

*I will pass out the surveys.

* Please complete part 1 and part 2 of the surveys to the best of your ability. If you do not know an answer, feel free to leave the answer blank.

*When you have completed the survey, fold it, and put your survey in this envelope (hold up large, addressed mailing envelope.)

*When all surveys have been collected, the envelope will be sealed and sent to an independent researcher.

*Again, no one at this bank will ever see your score.

*All branch employees, including myself, are being asked to participate. I haven't even seen the survey.

* There are many other branches participating in this survey as well.

*Please DO NOT DISCUSS THIS SURVEY WITH ANYONE OUTSIDE THIS BRANCH. This will ensure that the researchers get an accurate assessment of normal training effectiveness. If people know about the survey prior to receiving training, they may pay more than normal attention to training which will distort the findings.

5) Open envelope in front of staff and pass out surveys.

6) After all the completed surveys have been collected in the return envelope, put extra surveys in the envelope as well, seal it and mail with your regular outgoing mail.

7) Do not review surveys prior to mailing. Employees were promised verbally and in writing that no one at the bank would see their results.

If you have ANY questions, please call RESEARCHER at PHONE \# THANK YOU SO MUCH FOR ASSISTING WITH THIS IMPORTANT RESEARCH PROJECT! 
VIDEO AND COMMON CONSUMER LOANS PRODUCT'S MAGAZINE INSTRUCTIONS

ONE WEEK PRIOR TO THE STAFF MEETING

1) Hand out Common Consumer Loan Product's Magazine one week prior to staff meeting.

2) Ask staff to complete the Advanceline chapter prior to staff meeting.

3) DO NOT emphasize that employees should pay particular attention to this chapter in any way, otherwise the results will not track normal training effectiveness.

\section{THREE DAYS PRIOR TO THE STAFF MEETING}

Post a sign on a bulletin board which says:

"Staff meeting on (Date) .

(Remember to complete the Advanceline chapter of your Common Consumer Loan Product's Magazine prior to the meeting)

\section{MEETING DAY}

REMEMBER TO CONDUCT MEETING THE SAME AS YOU NORMALLY WOULD

1) Call meeting to order.

2) Say "We're going to start right off watching a video about our Advanceline product."

3) DO NOT ask employees to pay particular attention to the video or indicate that they will be given a survey after the video. If this is done, the survey results will be distorted.

4) After viewing the video, ask employees to put away their Common Consumer Loan Product's Magazines. Do NOT allow them to review them even briefly before putting the magazine away. Be sure no one refers to their magazine while completing the survey.

5) Read this announcement as written:

Our branch has been randomly selected to participate in a training method effectiveness study. We have been asked to 
complete a survey which will indicate product knowledge after completing the magazine and watching a video. We were not told about the survey prior to completing the magazine or watching the video on purpose, so our scores will

represent the normal product knowledge level after self-study and video training. We will not be giving our names. This branch will not even be identified, so your score will not be traced back to you and will not impact your job in any way. No one in this branch, the area, the region or this bank will ever see or be notified of your score. It is not mandatory that you complete this survey, however, your participation will enable the training department to develop the most effective training for a branch environment.

6) Describe the process as written:

*I will pass out the surveys.

*Please complete part 1 and part 2 of the surveys to the best of your ability. If you do not know an answer, feel free to leave the answer blank.

* When you have completed the survey, fold it, and put your survey in this envelope (hold up large, addressed mailing envelope.)

*When all surveys have been collected, the envelope will be sealed and sent to an independent researcher.

*Again, no one at this bank will ever see your score.

*All branch employees, including myself, are being asked to participate. I haven't even seen the survey.

* There are many other branches participating in this survey as well.

*Please DO NOT DISCUSS THIS SURVEY WITH ANYONE OUTSIDE THIS BRANCH. This will ensure that the researchers get an accurate assessment of normal training effectiveness. If people know about the survey prior to receiving training, they may pay more than normal attention to training which will distort the findings.

7) Open envelope in front of staff and pass out surveys.

8) After all the completed surveys have been collected in the return envelope, put extra surveys in the envelope as well, seal it and mail with your regular outgoing mail.

9) Do not review surveys prior to mailing. Employees were promised verbally and in writing that no one at the bank would see their results. 
If you have ANY questions, please call RESEARCHER at PHONE \#. THANK YOU SO MUCH FOR ASSISTING WITH THIS IMPORTANT RESEARCH PROJECT!

VIDEO, COMMON CONSUMER LOAN PRODUCT'S MAGAZINE PLUS MEETING INSTRUCTIONS

ONE WEEK PRIOR TO THE STAFF MEETING

1) Hand out Common Consumer Loan Product's Magazine one week prior to staff meeting.

2) Ask staff to complete the Advanceline chapter prior to staff meeting.

3) DO NOT emphasize that employees should pay particular attention to this chapter in any way, otherwise the results will not track normal training effectiveness.

4) Review Common Consumer Loan Product Meeting Leader's Guide to familiarize yourself with the meeting format.

\section{THREE DAYS PRIOR TO THE STAFF MEETING}

Post a sign on a bulletin board which says:

"Staff meeting on (Date) .

(Remember to complete the Advanceline chapter of your Common

Consumer Loan Product's Magazine prior to the meeting.)

MEETING DAY

REMEMBER TO CONDUCT THE MEETING THE SAME AS YOU NORMALLY WOULD

1) Call meeting to order. 
2 ) Conduct the meeting according to the Common Consumer Loan Product Meeting Leader's Guide format. Do NOT emphasize that employees should pay particular attention to the video or meeting. This will distort the results. Also, if many have not completed the Common Consumer Loan Product's Magazine, do NOT re-schedule this meeting.

3) After completing the Meeting Leader's Guide, ask employees to put away their Common Consumer Loan Product's Magazine. Do NOT allow them to review them even briefly before putting the magazine away. Be sure no one refers to their magazine while completing the survey.

\section{4) Read this announcement as written:}

Our branch has been randomly selected to participate in a training method effectiveness study. We have been asked to complete a survey which will indicate product knowledge after completing the product meeting. We were not told about the survey prior to completing the training on purpose, so our scores will represent the normal product knowledge level after a product meeting. We will not be giving our names. This branch will not even be identified, so your score will not be traced back to you and will not impact your job in any way. No one in this branch, the area, the region or this bank will ever see or be notified of your score. It is not mandatory that you complete this survey, however, your participation will enable the training department to develop the most effective training for a branch environment.

5) Describe the process as written:

*I will pass out the surveys.

* Please complete part 1 and part 2 of the surveys to the best of your ability. If you do not know an answer, feel free to leave the answer blank.

*When you have completed the survey, fold it, and put your survey in this envelope (hold up large, addressed mailing envelope.)

*When all surveys have been collected, the envelope will be sealed and sent to an independent researcher.

*Again, no one at this bank will ever see your score. *All branch employees, including myself, are being asked to participate. I haven't even seen the survey.

*There are many other branches participating in this survey as well. 
*Please DO NOT DISCUSS THIS SURVEY WITH ANYONE OUTSIDE THIS BRANCH. This will ensure that the researchers get an accurate assessment of normal training effectiveness. If people know about the survey prior to receiving training, they may pay more than normal attention to training which will distort the findings.

6) Open envelope in front of staff and pass out surveys.

7) After all the completed surveys have been collected in the return envelope, put extra surveys in the envelope as well, seal it and mail with your regular outgoing mail.

8) Do not review surveys prior to mailing. Employees were promised verbally and in writing that no one at the bank would see their results.

If you have ANY questions, please call RESEARCHER at PHONE \#.

THANK YOU SO MUCH FOR ASSISTING WITH THIS IMPORTANT RESEARCH PROJECT! 


\section{APPENDIX 4}

TELECONFERENCE MEETING NOTES 
Appendix 4

TELECONFERENCE MEETING NOTES

-Thank you for calling

-Plan to talk over details of survey itself then specific details of conducting this research

-Your branch was randomly selected to participate

Research training methods:

Video

Study guide

Video and study guide

Video, study guide and reinforcement meeting

Control group--no training

-Your training method was randomly assigned. I am the only person who knows what method you are using other than you. When your results come in, I won't even be able to identify your branch.

-Purpose:

I've done extensive research--very limited info. available on effective training methods. These results will be useful for this bank and all branching environments.

-This is research in live working environment not laboratory. Good--realistic environment, actual people

Bad--many factors can bias results

-That is why guidelines are so strict--everyone conducts the research the same way--no one in the branch is aware of the research beforehand.

-Packet should contain:

1) Training kit including product magazines

2 ) Return envelope with my address 
-Start with "open now" envelope. It contains:

1) Overview letter

Outlines: random selection

we are researching training method effectiveness

you have been randomly assigned specific method

Do not tell anyone--VERY IMPORTANT

Hold on to training kit--wait until after meeting to put away

* lists your method--again you and I are only ones who know your method.

Significance--branch employees may feel uncomfortable that someone will see their results and tie back to them. ABSOLUTELY NOT! No one knows your method, survey does not ask name or branch, there is no identifier--researcher won't even be able to ID branch. ASSURE EMPLOYEES.

- "Do not open" envelope

Please do not open until standing in front of staff and are instructed to do so in research procedure sheet. Why?--we need your results and lets people see you are a part of survey--not looking at their results.

-Return envelope

Completed surveys are put into envelope by employees. Do not review completed surveys-your employees have been promised in writing and in your comments no one will see results at bank.

-Training kit

Remember to hold onto it. Use only the pieces you are instructed to. After all surveys have been sent off, you can use the rest of the kit.

-TALK THROUGH INSTRUCTIONS

- Important additional points to cover

-All groups will be conducting research as similarly as possible.

-Please do not indicate to staff that they should "brush up" on credit products or Advanceline. 
-Please read instructions exactly as written to staff during meeting. DO NOT PARAPHRASE.

-Emphasize that participation is not mandatory.

-Do not indicate that employees should pay particular attention to training. Do not do anything that would draw special attention to the training in any way.

-My name and phone number--call with questions

-Thank you for your time. 


\section{BIBLIOGRAPHY}

Adler, Paul \& Clark, Kim (1991). Behind the Learning Curve: a sketch of the Learning Process. Management Science, 37 .

Adults in Higher Education (1987). Center for Educational Research and Innovation.

Andrews, Theodore E., Houston, W. Robert \& Bryant, Brenda L. (1981). Adult Learners (A Research Study). Association of Teacher Educators.

Beacham, Melissa (1991). Encouraging Participation from ALL Students. The Education Digest.

Berliner, D. C. \& Rosenshine, B. (1975, November 20-22). The acquisition of Knowledge in the Classroom. Paper

prepared for the Conference on Schooling and Educational Process, San Diego.

Bertrand, Kate (1990, Dec.) . Lights, Camera, Training! Business Marketing, 75, 12:16-18.

Bosco, James \& Wagner, Jerry (1988, June). A Comparison of the Effectiveness of Interactive Laser Disc and Classroom Video Tape for Safety Instruction. Educational Technology, 28, 6:15-22.

Brandt, Ron (1990). On Learning Styles: A Conversation with Pat Guild. Educational Leadership, 18 .

Burwell, Lawrence B. (1991, March). The Interaction of Learning Styles with Learner Control Treatments in an Interactive Videodisc Lesson. Educational Technology, $31,3: 37-43$.

Cockayne, Susan (1991, Feb.). Effects of Small Group Sizes on Learning with Interactive Videodisc. Educational Technology, 31, 2:43-45.

Curry Lynn \& Snider, Vicki (1990). A Critique of the Research on Learning Styles. Educational Leadership, 48 .

Dillon, J. T.(1991). Questioning the Use of Questions. Journal of Educational Psychology, 83.

Dunn, Rita (1990). Rita Dunn Answers Questions on Learning Styles. Educational Leadership, 48. 
Dunn, R., Beaudry, J. \&Klavas (1989). Survey of Research on Learning Styles. Educational Leadership, 46, 6:50-58.

Elliott, P. H. (1975). An Exploratory Study of Adult Learning styles.

Fossum, J. A., Arvey, R. D., Paradise, C. A. \& Robbin, N. E. (1986). Modeling the Skills Obsolescence Process: A Psychological/Economic Integration. Academy of Management Review, 11, 362-374.

Fox, William M. (1988, Sum.). Getting the Most From Behavior Modeling Training. National Productivity Review, 7, $3: 238-245$.

Fuhrmann, B. S. \& Grasha, A. F. (1983). A Practical Handbook for College Teachers. Boston: Little, Brown and Co.

Gagliano, Martha E., M.D. (1988, Oct.). A Literature Review on the Efficacy of Video in Patient Education. Journal of Medical Education, 63, 10:785-792.

Gall, M. D. and Gall, J. P. (1976). The Discussion Method. In N. L. Gage (Ed.), The Psychology of Teaching Methods. The Seventy-fifth Yearbook of the National Society for the Study of Education, Part I. Chicago: The National Society for the Study of Education.

Ganster, Daniel C., Williams, Steve \& Poppler, Paul (1991). Does Training in Problem Solving Improve the Quality of Group Decisions? Journal of Applied Psychology, 76.

Georgenson, D. (1982). The Problem of Transfer Calls for Partnership. Training and Development Journal, 36.

Gist, M., Bavetta, A. G. \& Stevens, C. K. (1990). Transfer Training Method: its Influence on Skill Generation, Skill Repetition, and Performance Level. Personnel Psychology, 43.

Gist, Marilyn, Schwoerer, Catherine \& Rosen, Benson (1988, Summer). The Influence of Training Method and Trainee Age on the Acquisition of Computer Skills. Personnel Psychology, 41, 255-266.

Gordon, Jack (1990, October). Where the Training Goes. Training: The Magazine of HRD, 51-69.

Houle, C. O. (1961). The Inquiring Mind. Madison: University of Wisconsin Press. 
Kelly, J. B. (1982). A Primer on Transfer of Training. Training and Development Journal, 36.

Knowles, M. S. (1970). Andragogy not Pedagogy. In S. M. Grabowski (Ed.). Adult Learning and Instruction. Wash. D.C. Adult Education Assoc.

Knowles, Malcolm (1973). The Adult Learner: A Neqlected Species. New York: Gulf Pub. Co.

Kreitlow, B. W. (1976, July). Innovation in Organizing Learning for Adults. In R. M. Smith (Ed.). Adult Learning: Issues and Innovations, ERIC.

Long, Huey B. (1983). Adult and Continuing Education. Teachers College Press.

Marzano, Robert J., Pickering, Debra J. \& Brandt, Ronald, S. (1990). Integrating Instructional Programs Through Dimensions of Learning. Educational Leadership, 47, 1725 .

McCarthy, Bernice (1990). Using the 4MAT System to Bring Learning Styles to Schools. Educational Leadership, 48 .

McDiarmid, G. Williamson (1990). Challenging Prospective Teachers' Beliefs During Early Field Experience: A quixotic Undertaking? (Theme: Pedagogical Content Knowledge). Journal of Teacher Education, 11,12-21.

McKeachie, W. J. (1971). Improving Teaching Effectiveness. office of Education.

Murphy, P. D. (1977, Feb. 22) . Strategies for College Teaching. Twenty-first annual faculty lecture, North Dakota State $U$.

Newstrom, John W. \& Lengnick-Hall, Mark L. (1991). One Size Does Not Fit All. Training and Development Journal, 45, 43-47.

O'Sullivan, Mary, Stroot, Sandra, Tannehill, Deborah \& Chou, Chien (1989, July-Aug.). Interactive Video Technology in Teacher Ed. Journal of Teacher Education.

Osguthorpe, N., Roper, J., \& Saunders, J. (1983). The Effect of Teaching on Medication Knowledge. Western Journal of Nursing Research, 5:205-216.

Phillips, Timothy L., Hannafin, Michael J., Tripp, Steven D. (1988, Summer). The Effects of Practice and Orienting Activities on Learning from Interactive Video. 
Educational Communication and Technology Journal, 36, $2: 93-102$.

Potter, W. James \& Emanuel, Richard (1990). Students' Preferences for Communication Styles and Their Relationship to Achievement. Communication Education, $39,3,234-249$.

Rosen, N. A., Williams, L. K. \& Foltman, F. F. (1965). Motivational Restraints in an Industrial Retraining Program. Personnel Psychology, 18, 65-79.

Ross, Randy (1988, Sep.). Technology Tackles the Training Dilemma. High Technology, 8, 9:18-23.

Shands, R. \& Brunner (1989). Providing Success Through a Powerful Combination: Mastery Learning and Learning Styles. Perceptions, 25.

Snow, R. E. \& Lohman, D. F. (1984). Towards a Theory of Cognitive Aptitude for Learning from Instruction. Journal of Educational Psychology, 76: 347-376.

Spitzer, Dean R., Bauwens, Jeanne, Quast, Sue (1989, May). Extended Education Using Video: Lessons Learned. Educational Technology, 29, 5:28-30.

Stalonas, P. M., Keane, T. M., \& Foy, D. W. (1979). Alcohol Education for Inpatient Alcoholics: A Comparison of Live, Videotape, and Written Presentation Modalities. Addictive Behavior, 4:223-229.

Tough, A. (1971). The Adult's Learning Projects. Ontario: Ontario Institute for Studies in Education.

Warnat, Winifred I. (1979, April). A New Dimension of Adult Learning: Inservice Education. Inservice. Syracuse, N.Y. National Council of State on Inservice Education.

Womack, Sid. T. (1989). Modes of Instruction. The Clearing House, 62.

\section{Lisa P. Davidson}

\section{4}

